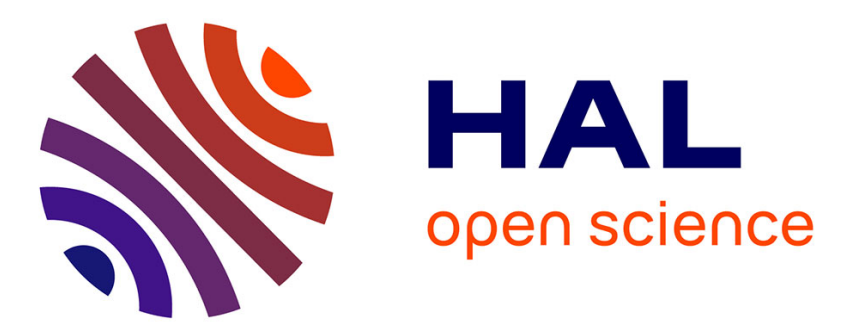

\title{
Voting Corrupt Politicians Out of Office? Evidence from a Survey Experiment in Paraguay
}

Rumilda Cañete, Josepa Miquel-Florensa, Stéphane Straub, Karine van Der

Straeten

\section{- To cite this version:}

Rumilda Cañete, Josepa Miquel-Florensa, Stéphane Straub, Karine van Der Straeten. Voting Corrupt Politicians Out of Office? Evidence from a Survey Experiment in Paraguay. Journal of Economic Behavior \& Organization, 2020, 179, pp.223-239. 10.1016/j.jebo.2020.08.046 . hal-03047130

\author{
HAL Id: hal-03047130 \\ https://hal.science/hal-03047130
}

Submitted on 8 Dec 2020

HAL is a multi-disciplinary open access archive for the deposit and dissemination of scientific research documents, whether they are published or not. The documents may come from teaching and research institutions in France or abroad, or from public or private research centers.
L'archive ouverte pluridisciplinaire HAL, est destinée au dépôt et à la diffusion de documents scientifiques de niveau recherche, publiés ou non, émanant des établissements d'enseignement et de recherche français ou étrangers, des laboratoires publics ou privés. 
January 2020

"Voting Corrupt Politicians Out of Office? Evidence from a Survey Experiment in Paraguay"

Rumilda Cañete, Josepa Miquel-Florensa, Stéphane Straub and Karine Van der Straeten 


\title{
Voting Corrupt Politicians Out of Office?
}

\section{Evidence from a Survey Experiment in Paraguay}

\section{Rumilda Cañete, Josepa Miquel-Florensa ’ Stéphane Straub ; and Karine Van der Straeten $\S$}

January 7, 2020

\begin{abstract}
This paper challenges the conventional wisdom that giving voters more power-both formally through the use of more "open" electoral systems and informally through easier access to information on politicians' wrongdoingswill necessarily result in them voting corrupt politicians out of office. Focusing on a comparison between closed-list and open-list proportional representation systems, we theoretically show that opening the lists is likely to generate a large shift of vote shares in favor of the traditional, most corrupt parties. We design a survey experiment to test these predictions in Paraguay and find strong supporting evidence. We do not find in our context that the lack of information is a major obstacle preventing voters from voting out corrupt politicians; if anything, under the more open system, supporters of the incumbent party tend to cast more votes for politicians with a recent history of corruption.
\end{abstract}

Keywords: Corruption, Electoral systems, Information

Acknowledgments: We thank CADEP (Centro de Análisis y Difusión de la Economía Paraguaya) for their logistic help in the implementation of the project. Funding from the IDEX-Emergence program at Uni-

*Independent researcher. rumistraub@gmail.com

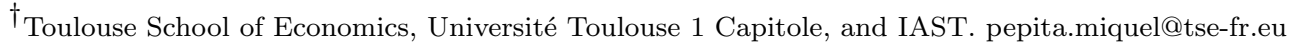

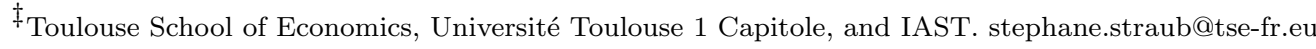

$\S_{\text {Toulouse School of Economics, CNRS, and IAST. karine.van-der-straeten } @ \text { tse-fr.eu }}$ 
versité de Toulouse, from CEPREMAP, from ANR under grant ANR-17-EURE-0010 (Investissements d'Avenir Program), as well as support through the ANR-Labex IAST (Institute for Advanced Study in Toulouse), are gratefully acknowledged. The design was preregistered in the American Economic Association's registry for randomized controlled trials (AEARCTR-0000531) and approved by the TSE-IAST review board for ethical standards in research (2016-05-001). We are grateful for comments from seminar participants in Bocconi, IADB, LSE, Madrid, Northwestern Kellogg, Paris School of Economics, Science-Po Paris, Universidad de Navarra, Universidad Javeriana, Universidad del Rosario, Fundation Getulio Vargas (Sao Paulo), Université Libre de Bruxelles, UNU-Wider Helsinki, TSE, Wisconsin and Yale, and especially from Andy Eggers, Heiko Giebler, Miriam Golden, and Susan Rose-Ackerman. We also thank Deborah Zak, Lizeth Fuquene and José M. Álvarez for excellent research assistance and Jean-Baptiste Grossetti for helping develop the survey materials. 


\section{Introduction}

Corruption is a major threat to economic and social development. ${ }^{1}$ It has the power to erode trust in political institutions, undermining the stability of political systems. ${ }^{2}$ Among the many remedies suggested, electoral democracy is often mentioned as a way to generate a better selection of politicians and to discipline them by creating incentives for reelection (Kunicova and Rose-Ackerman (2005); Ferraz and Finan (2008)). However, the literature has also established that democracy is no panacea and that, depending on the context, it is not necessarily conducive to less corruption (Stephenson (2015)). By and large, in many democracies, voters tend to elect and reelect corrupt politicians. ${ }^{3}$

To explain this puzzle of a regular reelection of corrupt politicians in democracies, the attention has shifted to studying conditions, which, combined with democracy, are necessary for voters to effectively exercise control over corrupt politicians. In particular, two important factors have been identified: (i) electoral institutions and (ii) voters' information.

Regarding the role of electoral institutions, the basic idea is that those that give voters more formal control over individual candidates, such as primaries in majoritarian systems or open-lists rather than closed-lists in proportional representation systems, grant voters more effective power over candidates. In addition, even if the electoral institutions formally allow voters to punish corrupt individuals, voters may still lack the relevant information to exercise this control in practice, either for external reasons (lack of access or absence of free press) or internal reasons (memory limitations, cognitive biases). Providing voters with more information should help them identify the corrupt politicians and "punish" them.

$1 \quad$ See Olken and Pande (2012) for a review of the related large body of work.

2 Lagunes (2012), Rose-Ackerman (1999), Rose-Ackerman (2005), Seligson (2002), Anderson and Tverdova (2003).

3 Within democracies, many studies have examined the effects of corruption charges on electoral performance across a variety of countries and institutional settings. Almost all of them find null or very modest effects (Peters and Welch (1980); McCann and Dominguez (1998); Winters and Weitz-Shapiro (2012); Bagenholm (2013)) 
In this paper, we challenge this conventional wisdom that giving voters more formal power-through more "open" electoral systems-and more information about politicians' wrongdoings will necessarily result in them voting corrupt politicians out of office. We focus on the comparison between closed- and open-list proportional representation $(\mathrm{PR})$ systems. The two systems are quite similar in that they both involve party lists with PR, but they vary in the degree to which they allow voters to express preferences about individual candidates. In practice, there is a wide variety of open-list systems, which themselves differ in how much formal power they give to voters. In particular, they differ with respect to the maximal number of candidate votes a voter is allowed to cast: it can be one (e.g., Sweden and Denmark), some fixed number larger than one (e.g., post-WWII Italy, where the maximum number of votes was three or four), or unlimited (e.g., Latvia). In this paper, we focus on the open-list system that gives the voters the maximum possibility to express themselves (and avoid potential coordination problems): we study, both theoretically and experimentally, an open-list system in which voters can vote for any number of candidates on the list, without any constraint. We make three main contributions.

First, we contribute to the theoretical debate about voters' formal control by highlighting a thus far neglected countervailing effect of open-list systems. The conventional argument in favor of open-list systems as a remedy against corruption is that voters, when voting for a list in an open-list system, can also express their preferences over the individual candidates on this list-a possibility absent in a closed-list system. This argument implicitly assumes that voters vote for the same parties under both systems (this is a "within-list" argument). We propose a theoretical model of voter behavior in closed- and open-list PR systems that explicitly models both the (within-list) candidate vote choice (in the open-list system) and the between-party vote choice (in both systems). We show that moving from a closed-list system to an open-list system is likely to increase the vote shares of the incumbent parties, which are likely to be the most corrupt. The intuition for this novel "between-list" effect is as follows. Opening the lists is more beneficial to lists that exhibit candidates over which voters have strong preferences. Indeed, if all candidates on a list look 'neutral' to a voter, 
she will not be more likely to vote for this list under the open-list system than under the closed-list system. The option to exercise the formal power given by open-lists has higher value for lists featuring not only candidates that the voters strongly like but also candidates that the voters strongly dislike. In a similar vein, opening the lists will also be more beneficial for lists whose candidates are well-known to the voters (again, either as good or bad). ${ }^{4}$ In many contexts, candidates running for large, incumbent parties are generally better known by voters and are likely to generate stronger feelings. Our theoretical findings imply that incumbent parties are likely to get higher vote shares-and thus more seatswhen opening the lists. These incumbent parties happen to often be the most corrupt, thus the negative impact on corruption.

Second, we test our main prediction in a survey conducted in Paraguay, including 2,641 individuals, 1,547 in the capital city Asunción and 1,094 in a rural area called Caaguazú. Respondents were asked to take part in two hypothetical elections, one under closed-list PR and one under open-list PR, featuring the same party lists they faced in the previous senatorial election. Paraguay is an institutionally weak democratic country ranked consistently among the most corrupt in Latin America. It is an interesting country to study since it currently uses a closed-list PR system to elect its members of the Senate, but there is an ongoing debate about a potential electoral reform to open the lists. Interestingly, one of the main arguments put forward by advocates of the open-list reform is its expected ability to tackle corruption. Consistent with our theoretical predictions, we find a large shift in vote shares towards the incumbent party at the expense of smaller parties when lists are opened, even though this incumbent party is widely perceived as corrupt by voters. When opening the lists, the fraction of participants voting for the incumbent increases by between 6 or 7 percentage points (a 13 percent relative increase), with a same magnitude drop in the number of voters voting for the smaller parties with candidates less

$4 \quad$ Our model shares similarities with that of Blumenau, Eggers, Hangartner, and Hix (2017), who propose a model of voting under closed-list and open-list systems, showing that the latter is likely to benefit parties with more internal disagreement on key issues. They study a case where voters can only cast one candidate vote under the open-list PR system, but the intuition is similar. 
well-known to the public (which represents a 28 percent relative drop).

Third, our survey allows us to evaluate in this Paraguayan context the assumption lying at the basis on the conventional argument in favor of opening the lists, namely, that under the open-list system, voters would use the additional formal power granted by this electoral institution to vote against corrupt politicians, especially when they have good information about these politicians' past wrongdoings. Before the respondents were invited to vote in the hypothetical election featuring the candidates who ran in the previous 2013 Senate election, we randomized information reminding them about a highly publicized corruption scandal involving 23 of these politicians. Studying votes for individual candidates under the open-list system, we find that our information treatments have little to no impact on vote choice. We interpret this null result as suggesting that the lack of information is not the main obstacle preventing voters from voting against corrupt politicians when given a chance. We even provide suggestive evidence that, if anything, supporters of the incumbent party tend to give more votes to politicians involved in the corruption scandal.

Taken together, our results challenge the optimistic view that voters' information and formal control are necessarily helpful tools when fighting corruption.

The remainder of this paper is structured as follows. The next section reviews in more detail the literature on the impact of democratic institutions and voters' information on corruption and highlights our specific contributions. In Section 3, we lay out a model of voter behavior in closed- and open-list PR systems and derive testable predictions. Section 4 describes the Paraguayan setting, and Section 5 details our experimental and survey design. We discuss the results in Section 6. The last section concludes.

\section{Literature Review and Contribution}

The optimistic view about democracy holds that free elections should allow voters to vote corrupt politicians out of office. This threat to their reelection prospects should in turn prevent office-motivated politicians from engaging in corrupt activ- 
ities. The implication is that democracies should be more immune to corruption than nondemocratic countries. Summarizing a large stream of the literature, Stephenson (2015) concludes that there is little evidence supporting this claim. Within democracies, by and large, corrupt politicians are typically reelected, even after being convicted for wrongdoings.

This raises the question of how and in which circumstances democratic institutions may empower citizens and enable them to better control politicians. At least two conditions have been identified as essential: (i) the details of electoral institutions create more or less incentives for politicians to engage in corruption and make it more or less costly for voters to vote against corrupt candidates, and (ii) to exercise the formal power given by democratic institutions, voters also require relevant information about politicians' wrongdoings. Below, we review the literature and explain how our paper contributes to each of these two dimensions.

The role of electoral institutions. As noted by Rose-Ackerman (2005), electoral institutions differ in the opportunities they provide for legislators to engage in corrupt activities, as well as in the incentives and abilities for voters and opposition to monitor, unveil, and punish corrupt activities by incumbents. For example, comparing majoritarian and PR systems, Persson and Tabellini (2000) argue that voting over individual candidates (as in a majoritarian system) rather than over lists (as in a closed-list PR system) creates a direct link between a politician's performance and re-election. This, in turn, gives politicians incentives to avoid corruption (Persson, Tabellini, and Trebbi (2003)). Since open-list PR shares with plurality this feature of having voters vote directly on candidates, open-list PR should be superior to closed-list PR. ${ }^{5}$

There are nevertheless a number of potential countervailing effects (Stephenson (2015)). ${ }^{6}$ While voters have more power in open-list systems, party discipline is

$5 \quad$ As summarized in Rose-Ackerman (2005) "plurality rule voting ought to do a better job at controlling corrupt political rent-seeking than PR, especially closed-list PR. (...) Because open-list PR systems share features of both closed-list PR and plurality systems, they occupy an 'intermediate' category in monitoring corrupt self-enrichment." (p. 54)

6 These countervailing effects may explain why empirical studies that compare open- 
presumably stronger in closed-list systems, where candidates totally rely on parties to get elected. If parties are more effective than voters in disciplining politicians, one may expect more corruption in open-list systems. Furthermore, by inducing fiercer intraparty competition, open-list systems may induce politicians to engage in more unlawful activities to attract votes (instrumental corruption) ${ }^{7}$

In this paper, we unveil a new countervailing effect. We start by noting that the standard argument about giving voters more control in the open-list systems focuses exclusively on voters' choice within parties. We show that explicitly modeling vote choice between parties yields a rather different picture. A recent paper by Blumenau et al. (2017) argues that a move from closed- to open-list system is likely to be more favorable to parties with more internal disagreement on key issues. ${ }^{8}$ We propose a simple decision-theoretic model of voter behavior that explores similar arguments in the case of corruption. We show that in theory opening the lists is likely to benefit the most corrupt parties and that this prediction is supported by our experimental findings in the Paraguayan context.

Note that compared with the previous literature on countervailing effects that centers on parties and candidates strategies, our controlled experiment setting allows us to abstract from this list-level endogeneity, and to compare the incentives for voters to vote for the different lists holding all other things equal, especially the quality of the candidates. In doing so, we avoid the confounding effects that may affect existing empirical studies comparing open- and closed-list PR and are likely to be the reason these reach inconsistent conclusions.

The role of information. As reviewed above, the main argument in favor and closed-list PR reach inconsistent conclusions. Some find that closed-list PR systems are associated with higher perceived corruption than open-list systems (Chang and Golden (2007); Persson et al. (2003); Tavits (2007); Kselman (2011); Nyblade and Reed (2008)), while others find that they have lower perceived corruption (Brown, Touchton, and Whitford (2011); Potter and Tavits (2012)), and many studies fail to find evidence of a significant difference (Kunicova and RoseAckerman (2005); Serra (2006); Schleiter and Voznaya (2014)).

7 Chang (2005) provides evidence of such an effect in post-World War II Italy.

8 They provide experimental evidence supporting this claim by conducting a survey experiment in the context of a hypothetical EU election in the UK. They show that using an open-list ballot shifts support from the UKIP Party (a niche party defending Eurosceptic views) to the Eurosceptic candidates of the Conservative Party (which is internally divided on the European integration issue). 
of democratic institutions as an effective tool to fight corruption is that voters are hurt by corruption and are ready to punish politicians. In contexts in which electoral institutions allow voters to individually punish corrupt politicians, the lack of information may be the main obstacle preventing voters from exerting control.

A number of papers have indeed shown that voters' information and a high salience of the corruption issue are key in generating punishment by voters. Chang, Golden, and Hill (2010) study the legislatures that sat in Italy's lower house between 1948 and 1994, elected with an open-list system. They show that corrupt politicians were only punished by voters after the heavy media coverage of political corruption accompanying the Clean Hands operation in the early 1990s. Ferraz and Finan (2008) and Melo, Pereira, and Figueiredo (2009) find large negative effects on the probability of reelection in Brazil when examining the effect of audits reporting corruption.

Recently, a few field experiments have provided conflicting results about the role of information. Banerjee, Kumar, Pande, and Su (2011) find that providing Indian voters with information induces higher turnout and higher vote shares for more qualified candidates. Chong, De La O, Karlan, and Wantchekon (2014) provide experimental evidence during local elections in Mexico that information decreases incumbent party support but also decreases voter turnout and support for a challenger party. Arias, Larreguy, Marshall, and Querubin (2018) argue that whether voters punish politicians when learning new information on wrongdoings depends on their prior beliefs and how they are updated.

The Metaketa Initiative of the Evidence in Governance and Politics (EGAP) network builds on the previous literature by performing a pre-registered metaanalysis of seven randomized controlled trials conducted in six countries by independent research teams (Dunning et al. (2019)). It concludes to the absence of overall evidence that information campaigns influence voter behavior.

While all these papers use measures of turnout and vote shares at the precinct level as dependent variables, we study how voters react to information about corruption at the individual level. The fact that we have individual vote outcomes 
allows us to improve on previous studies by analyzing heterogeneity along a number of dimensions, including political preferences such as party attachment, education and income. ${ }^{9}$ We find very little evidence in the Paraguayan context that voters dislike corrupt politicians and vote against them when given the opportunity. If anything, under the open-list system, supporters of the incumbent party tend to cast more votes in favor of candidates who were involved in a recent corruption scandal. At least in our context, information does not seem to be the most important barrier preventing voters from voting against corrupt politicians.

\section{A Theoretical Comparison of Closed-list and Open-list Proportional Representation}

We propose a simple model to explicitly compare which parties voters choose to vote for under closed- and open-list PR systems. ${ }^{10}$

\subsection{Assumptions}

Most of the existing literature emphasizing the potential adversarial effects of opening the lists has focused on the differences in incentives parties and candidates face under the two systems. Our model unveils another negative effect, which stems solely from voter behavior. To analyze this new channel separately, we hold the characteristics and strategies of the parties and of the candidates fixed under both systems. ${ }^{11}$

Assume that a voter faces a choice between $L$ parties, each presenting a list of $K$ candidates. We assume that voters derive some intrinsic 'consumption utility' from supporting a party and/or candidates they like and voting against candi-

$9 \quad$ This is crucial in the Paraguayan setting (and in many Latin American countries; see, for example, Gonzalez Ocantos, de Jonge, and Nickerson (2014)), where vote buying, distrust and lack of information about the democratic system are likely to vary considerably across different demographic groups.

10 See Appendix A for a discussion and extensions.

11 Note that this is also consistent with our experimental strategy, since in our voting experiment respondents vote under both systems for the same set of candidates and with the same information. 
dates they dislike. We further assume that this expressive utility is independent of other voters' decisions. Since we assume away any strategic interactions across voters, in the rest of this subsection, we consider one individual voter in isolation. Formally, we make the following assumptions:

Assumption 1 [ABstention]: Whatever the system, we normalize to 0 the utility the voter obtains if she abstains.

Assumption 2 [Subjective Ratings of parties]: The voter attaches a subjective value to each of the $L$ parties. This value is independent of the specific candidates running on the party list. It reflects the general congruence between the party and the voter, her personal history or any links she may have with this party. Denote by $u^{l}$ the value attached to party $l$ by the voter. We assume that $u^{l}$ can take any real value, positive or negative, and that for any given party, it is the same under both systems. A positive (negative) rating means that the voter likes (dislikes) this party.

Assumption 3 [Subjective Ratings of CAndidates]: The voter attaches subjective values to each of the $L * K$ candidates running on the lists. For $l=1, \ldots, L$ and $c=1, \ldots, K$, we denote by $q_{c}^{l}$ the "subjective value" attached to candidate $c$ on list $l$. We assume that $q_{c}^{l}$ can take any real value, positive or negative, and that for any given candidate it is the same under both systems. A positive (negative) rating means that the voter likes (dislikes) this candidate.

Under the closed-list system, when the voter votes for a list, she has no way of distinguishing among candidates on this list. In a way, she must "passively" vote for all the candidates on this list. We capture this feature by the following assumption:

Assumption 4 [ClOSED-LIST]: Under the closed-list system, the expressive utility the voter derives from voting for list $l$ is given by the following:

$$
U_{\text {closed }}^{l}=u^{l}+\left(\sum_{c=1, \ldots, K} q_{c}^{l}\right)
$$

The first component is her general utility for the party $\left(u^{l}\right)$. The second component is the total (subjective) evaluation of the candidates on the list. The fact 
that the voter must passively vote for all the candidates on the list is captured by the equal weight put on all candidates' ratings. Note that the voter suffers a utility loss if some candidates on the list have a negative rating.

We consider an open-list system where, when the voter votes for a list, she must also make a decision regarding each single candidate on this list, i.e., whether she wants to "actively" vote for this candidate or not. Since the decision for each single candidate is binary (vote for this candidate or not), in the sequel, we will also say that a voter votes "against" a candidate if she does not vote for him. The ability to discriminate among candidates under an open-list system is captured by the following assumption:

Assumption 5 [Open-LIST]: Under an open-list system, the expressive utility the voter derives from voting for party list $l$ and for a subset of candidates $\mathcal{C}$ on this list is given by the following:

$$
U_{\text {open }}^{l, \mathcal{C}}=u^{l}+\left[\left(1+\Psi^{+}\right) *\left(\sum_{\substack{c=1, \ldots, K: \\ c \in \mathcal{C}}} q_{c}^{l}\right)\right]+\left[\left(1-\Psi^{-}\right) *\left(\sum_{\substack{c=1, \ldots, K: \\ c \notin \mathcal{C}}} q_{c}^{l}\right)\right],
$$

where $0 \leq \Psi^{-} \leq 1$, and $0 \leq \Psi^{+}$.

The first component is again her general utility for the party $\left(u^{l}\right)$. The second component is the sum of the ratings of the candidates she actively votes for on the list, weighted by some parameter $\left(1+\Psi^{+}\right)$, with $1+\Psi^{+} \geq 1$. This captures the idea that the (positive or negative) utility derived from actively voting in favor of a candidate is larger in absolute value than the utility derived from passively voting for the same candidate in the closed-list system (remember that in the closed-list system, the weight on the subjective rating of each candidate is 1). The third component is the sum of the ratings of the candidates she votes against, weighted by another parameter $\left(1-\Psi^{-}\right)$, which is assumed to be positive but smaller than 1 . The (positive or negative) utility derived from actively voting against a candidate is smaller in absolute value than the utility derived from passively voting for the same candidate in the closed-list system. Parameters $\Psi^{+}$ and $\Psi^{-}$can be interpreted as psychological parameters describing respectively how much the voter values being able to actively vote for, and against, individual 
candidates under the open-list system.

Assumption 6 [Voter Choice]: Under each system, the voter identifies the list - and under the open-list system the subset of candidates within this list - yielding the highest utility. If this maximal utility is negative, she abstains; otherwise, she votes for this list (and under the open-list system this subset of candidates within the list).

Note that the subjective ratings of parties and candidates introduced in Assumptions 2 and 3 are voter-specific; they measure the congruence between the party/candidate and the voter. It is important to note that at this stage, we make no specific assumptions regarding how these subjective ratings relate to objective characteristics of the parties and candidates, such as their level of corruption. In the standard argument in favor of open-list systems, the implicit assumption is that they correlate negatively with the candidates' level of corruption. In our model, we remain very general and allow for any kind of voter preferences. $^{12}$

This very simple model captures the main differences, from the voter perspective, between a closed- and an open-list system. It makes some nontrivial and novel predictions about the comparison between these two systems.

\subsection{Predictions}

To draw this comparison between the two systems, we first derive the optimal vote choices implied by Assumption 6 under each system.

Closed-list system In the closed-list system, the choice is quite straightforward since it only entails comparing the utilities for parties defined in (1) and the utility for abstention (normalized to 0 according to Assumption 1).

Open-list system In the open-list system, the voter chooses to vote or abstain, but if voting for a party, she also chooses a subset of candidates from this party. It is straightforward from (2) that conditional on voting for party $l$,

12 These subjective measures are impacted by the quality of voters' information. In Appendix A, we propose a formal derivation of these subjective evaluations, where we explicitly model the role of uncertainty and imperfect information. 
the voter should vote for all the candidates with a strictly positive evaluation $\left(q_{c}^{l}>0\right)$ and should vote against/not vote for any candidate with a strictly negative evaluation $\left(q_{c}^{l}<0\right)$. Regarding the candidates such that $q_{c}^{l}=0$, she is indifferent between voting for them or not. Denote by $U_{\text {open }}^{l *}$ the utility resulting from this optimal choice of candidates within list $l$.

This simple remark illustrates that, within lists, opening the lists benefits candidates who receive a positive evaluation from a large number of voters and hurts candidates who receive a negative evaluation from a large number of voters. In particular, if voters' ratings of candidates are negatively correlated with the candidates' level of corruption, this remark captures the standard argument in favor of open-lists, namely, that they give voters the opportunity to vote against "bad" corrupt politicians.

For each list, we can now explicitly write the difference between the maximum utility under open-list $\left(U_{\text {open }}^{l *}\right)$ and the utility a voter derives from voting for this same list under the closed-list system $\left(U_{\text {closed }}^{l}\right)$ :

$$
U_{\text {open }}^{l *}-U_{\text {closed }}^{l}=\left[\Psi^{+} * \sum_{\substack{c=1, \ldots, K: \\ q_{c}^{l} \geqslant 0}} q_{c}^{l}\right]+\left[\Psi^{-} * \sum_{\substack{c=1, \ldots, K: \\ q_{c}^{l}<0}}\left|q_{c}^{l}\right|\right]
$$

Equation (3) first shows that whatever the list, the utility derived by the voter from voting for a list is at least as high in the open-list system as in the closed-list one. This result is quite intuitive. Indeed, in the open-list system, there is an increased weight in her utility of the value of the candidates the voter likes (and thus votes for) $\left(q_{c}^{l}>0\right)$ and a reduced weight of the value of the candidates she does not like (and thus votes against) $\left(q_{c}^{l}<0\right)$.

Since, in both systems, the value of abstention is normalized to 0 (Assumption 1) and a voter votes if and only if at least one list yields a positive utility (Assumption 6), our first proposition is that abstention should be (at least weakly) lower in the open-list system than in the closed-list system.

Proposition 1 (EFFECT of Open-LiSts on ABSTEntion): Opening the lists decreases abstention. 
Second, equation (3) also shows that this increase in utility is likely to be heterogeneous across party lists. The difference is larger when the list has many candidates the voter likes (the $\sum_{c=1, \ldots, K: q_{c}^{l}>0} q_{c}^{l}$ term) but also interestingly when the list has many candidates the voter dislikes (the $\sum_{c=1, \ldots, K: q_{c}^{l}<0}\left|q_{c}^{l}\right|$ term). This leads to Proposition 2:

Proposition 2 (BetweEn-LIST EFfeCts): Opening the lists benefits lists with candidates over which voters have strong preferences, either positive or negative.

The finding about candidates with bad ratings is particularly interesting. If a voter likes a party but strongly dislikes some candidates on its list, under the closed-list system, this voter might choose to abstain or vote for another party. When the lists are opened, the voter can now cross out politicians she does not like, which might induce her to cast a vote in favor of this initial list.

Proposition 2 has an interesting corollary in terms of information. Indeed, note that the level of information the voter has about the candidates on the lists is likely to affect the strength of voter preferences (i.e., the magnitude of the $\left.\left|q_{c}^{l}\right|\right)$. When a candidate is highly present in the media or is well known to the voter because he/she has been in office for a long time, he/she is likely to generate strong views and feelings, either positive or negative. Proposition 2 therefore implies that opening the lists is likely to benefit parties with wellknown candidates, over which voters have strong feelings, independently of their 'true' quality and of whether voters like them or not. Which parties are these in practice? In many contexts, these are likely to be the large, incumbent parties. Indeed, incumbent parties generally have more visible, better-known candidates. Candidates from the parties in power enjoy more exposure in the media, either because they have been more active when in power or because they benefit from more campaign funds and relevant resources from their party. In weak democratic contexts, the incumbent parties are often associated with the highest levels of perceived corruption. In these contexts, Proposition 2 implies that the most corrupt parties are the ones likely to benefit from these between-list effects of opening the lists. 
Another interesting implication of equation (3) is that the effects of opening the lists are likely to be heterogeneous across voter groups, depending on their general political information. Indeed, the level of information a voter has about the candidates on the lists is likely to affect the strength of her preferences (i.e., the magnitude of the $\left.\left|q_{c}^{l}\right|\right)$. A voter with poor information about the candidates running on the different lists is likely to have subjective evaluations of the candidates close to 0 . In contrast, a sophisticated voter who has a good general knowledge about the qualities and the characteristics of the candidates is likely to have stronger feelings (either good or bad) about the various candidates running on the list. Only in that case will he/she be able to exploit the additional opportunities offered by the open-list systems to express his/her preferences for individual candidates. ${ }^{13}$ This result is stated in Proposition 3:

Proposition 3 (Heterogeneous effects): The consequences of opening the lists described in Propositions 1 and 2 are expected to be stronger (in magnitude) for voters who are well-informed about politics in general and who are politically more sophisticated.

Proposition 3 points to a potential political inequality in how citizens use the opportunities offered by open-list systems. In the Paraguayan context, these politically well-informed, sophisticated voters will be overrepresented in the sample of respondents from the Capital city Asunción, compared to our rural sample.

\section{The Paraguayan Context}

\subsection{The General Political Setting}

Paraguay emerged from the longest-standing right-wing dictatorship in Latin America in 1989 (See Straub (2014)) for an overview of the recent political history of Paraguay). It is a country with weak institutions, a very corrupt political class with large-scale clientelism and widespread vote-buying at election time (Finan and Schechter (2012)). Public firms are the target of intense rent-seeking, for

13 We formalize the predictions about the quality of information in Appendix C. 
example in the case of the large dam Itaipú (See Straub (2015)). Paraguay has ranked consistently among the most corrupt countries in Latin America. ${ }^{14}$

On a national level, Paraguay elects a head of state-the president-and a legislature. The president is elected for a five-year term. The National Congress (Congreso Nacional) has two chambers: the Chamber of Deputies (Cámara de Diputados) has 80 members, and the Chamber of Senators (Cámara de Senadores) has 45 members. All members of the Senate, which is the focus of the experimental part of this paper, are elected for a five-year term by closed party-list proportional representation with universal suffrage, in a national circumscription.

Interestingly, in recent years, there has been a discussion about opening the lists, particularly as a way to address corruption. Closed-lists are referred to locally as "listas sábanas" ("blanket lists") and are widely considered to favor corrupt candidates. ${ }^{15}$

Paraguay has long been characterized by a strong two-party system. The main party is Associación Nacional Republicana (ANR), locally known as the Colorado (red) Party. It has been in power since 1947, including the 35 years of the dictatorship of Alfredo Stroessner, with only one interruption during the 2008-2013 period. The other historical party is the Partido Liberal Radical Auténtico (PLRA), known as the Liberal (blue) Party. It has been the main opposition party for most of the period when the Colorado were in power. In the 2013 election, the Colorado and Liberal Parties together captured $71 \%$ of the seats in the Senate and $89 \%$ in the Chamber of deputies.

Apart from these two main parties, the two other parties that won Senate seats in the 2013 election were the Frente Guasú (Concentración Nacional Frente Guasú - FG), led by former president Lugo, and Partido Democrático Progresista

14 In 2016, Paraguay ranked 123 out of 176 countries in the Transparency International Corruption Index, and from 1998 to 2006, it ranked in the lowest 10 percent on Control of Corruption Indicators (WBGI).

15 See, for example, a compilation of news articles on the topic in the newspaper ABC: http://www.abc.com.py/tag/listas-sabana9228.html, and the site of an association fighting for opening of lists: https://asofueralistasabana.blogia.com/2014/101105-la-lucha-por-el-desbloqueode-listas-en-el-paraguay.php. 
(PDP), with 5 and 3 seats, respectively. These two smaller parties both run on more progressive, anticorruption platforms.

Political life is generally characterized by a low degree of public involvement, with little knowledge of and volatile trust in political institutions. Interestingly, the results from opinion polls and from our own survey (See Tables C1 and C2 in Appendix C) show that the two main parties are perceived as equally corrupt. Nevertheless, voters' identification with their party of choice is quite strong, often across many family generations (Table C3).

\subsection{The Bogado Scandal: "The Golden Nanny"}

Our experimental design uses a corruption scandal involving the Congress that was elected in April 2013. Following the publication of information on public institutions' payrolls in November 2013, a number of high-profile corruption scandals involving members of Congress erupted. Senators who had abused the public servant law to obtain numerous remunerations for their family and friends were exposed. However, the Senate refused to lift parliamentary immunity to allow for the judicial investigation of one of its members, Victor Bogado (from the Colorado party), by a narrow margin (23 Senators out of 45 voted against lifting Bogado's immunity). ${ }^{16}$ Known as "niñera de oro" ("Golden Nanny"), the case involved Bogado's "nanny", who had two simultaneous very well-paid full-time jobs, in Congress and in the State company Itaipú. Contrasting with the usual apathy of Paraguayan citizens, these facts spurred a strong public outburst of indignation, both in social networks and in the street. A striking and unprecedented reaction was that numerous shops in capital city Asunción posted signs saying that the 23 senators who voted against lifting immunity were not welcome there. This eventually led the Senate to revert its decision.

A noteworthy feature is that this scandal involved in quite similar terms the two main political parties, the governing Colorado Party (ANR) and the main opposition Liberal Party (PLRA), as senators from both of them voted to protect

16 See Figures B4 and B5 for lists of all Senate members and of those who voted to protect Bogado, respectively. 
their colleague (excluding Bogado himself, 13 were from the Colorado party ${ }^{17}$ and 9 from the Liberal party). In that sense, the impact is unlikely to be the simple expression of one-sided political preferences. ${ }^{18}$

\section{Experimental Design and Data Collection}

Our survey was run during the spring of 2015, that is, two years after the elections that took the Colorado Party back to power and one year after the Bogado scandal (See Figure 1). Our survey consisted of three components: (i) a first set of questions on the household socioeconomic characteristics, (ii) a voting experiment, and (iii) a set of questions about political attitudes.

\subsection{Description of the Voting Experiment}

The voting experiment consisted of the following. ${ }^{19}$

The "scandal reminder" treatment. Before the hypothetical elections took place, we presented all respondents with a 3-page-long news booklet. In a between-subject design, the first two pages were common for all participants: the first page was about a young Paraguayan player being recruited by the top European soccer team FC Barcelona, and the second one was about '7 Cajas', a Paraguayan movie, which obtained international recognition. Information was randomized on the third page. The control group was presented with the pictures and names of all the Senators elected in the 2013 election. We had two treatments containing different reminders about the corruption scandal involving Senator Bogado. Treatment 1-Treatment Corruption-was a simple reminder of the fact that 23 senators voted against removing impunity and hence tried to stop the judicial trial against Bogado. The names, pictures, and parties of these senators were given. Treatment 2-Treatment Corruption Social-highlighted, together with the pictures of the 23 senators, the social punishment this scandal

$\overline{17}$ From them, two later left the party and were listed as independent at the time of our experiment.

18 Bogado was reelected in the 2018 Senate election. He was finally sentenced to a one year suspended jail term in May 2019 and soon after ousted from the Senate.

19 All experimental materials and protocol text are presented in Appendix B. 
generated, in the form of these senators not being allowed into some public places or businesses.

The two hypothetical elections. Each respondent was asked to take part in two successive hypothetical votes to elect their senators (within-subject design). ${ }^{20}$ The experimental ballots were based on the lists of candidates who actually ran in the 2013 election. In the 2013 Senate election, there were 22 lists of 45 names each. To avoid having ballot forms that were too long, we restricted the choice set to the four main lists (Colorado (ANR), Liberal (PLRA), Frente Guasú (FG), Partido Democrático Progresista (PDP)) and to the 20 first candidates in each list. All the candidates actually elected in 2013 were on our experimental lists. Respondents first voted with the closed-list system and then with the open-list system. ${ }^{21}$ In the closed-list election, voters could choose one of the lists or abstain. In the open-list election, they could similarly choose one of the lists (or abstain) and had the added option of crossing out one or more names on that list. There was no limit on the number of names they could cross out. To respect the secrecy of the votes, respondents were invited to move away from the interviewer while they were filling in the ballots. Once they had completed the two ballots, they put them inside sealed envelopes and handed them back to the interviewer.

\section{Description of the candidates included in the voting experiment.}

We provide in Table $\mathrm{C} 4$ the descriptive statistics on the 20 candidates included in the experiment for the main two parties (Colorado and Liberal). Candidates have been in the Senate for 8 years on average. As per gender, 15 percent of the incumbent party candidates are women, as opposed to 31 percent for the Liberal Party.

20 See the details of the protocol in Appendix B.

21 Closed-lists was the voting system presented first to the individuals, given that it is the current system in Paraguay and hence is well known to the participants. Even if raising usual ordering effect concerns, we believe that this order helped a population not familiar with abstract thinking to ground the voting idea for the posterior explanation of the open-list system, and it also reflected the potential real-world transition. Given the potential anchoring effect generated by the closedlist vote, this means that our results are likely to be lower bounds on the actual effects. 
In addition, we collected information on the candidates' public exposure and proxies for corruption: whether they are present on Facebook and Twitter, the number of mentions of their name in the main local newspaper (ABC Color), and regarding corruption exposure in the media, the number of mentions of their name with the word 'corruption', in the same main local newspaper (ABC Color). ${ }^{22}$

In most of our subsequent analyses, we will use as a proxy for a candidate's level of corruption a dummy indicating whether he or she was involved in the Bogado scandal. We use the media measure of corruption to validate this experimental proxy. In the sample of 40 candidates, the correlation between the standardized z-score of media corruption mention and a dummy variable indicating whether a candidate is exposed in the experiment as part of the 23 who voted to protect Bogado is 0.31, with a p-value of 0.052 . Table C5 shows ttests across the main characteristics for involved vs. non-involved candidates. Involved candidates appear to be mostly males, more experienced, ranked higher on the list, more often tied to corruption in the media, and more present on social media. The last four characteristics are individually significant, and all are jointly significant.

\subsection{Implementation and Experimental Sample}

A pilot was conducted by the authors and the team of enumerators in March 2015. The final survey was implemented between April and June 2015 in two areas of Paraguay: the capital Asunción and the rural area of Caaguazú (See Figure 2).

In each area, we selected neighborhoods and streets, and enumerators walked in every other house. Randomization of the information treatment was done at the household level. Whenever willing, the present adult household member was interviewed. Whenever the spouse of the main respondent was present and accepted to take part in the survey, we also interviewed him or her, with an

22 We use a count of these mentions between June 30, 2013, which is the date the new legislature took office, and March 30, 2015, the end of the month immediately before our experimental rollout. 
additional randomization of the treatment within couples. ${ }^{23}$

The final database includes 1,547 individuals in Asunción and 1,094 in Caaguazú. Table C6 shows that our sample is well balanced across treatments. Table C7 presents the comparison of our sample with the 2015 National Household surveys, for the two regions separately, showing that the subsamples are quite representative at the regional level. Table C8 shows that respondents in the rural area of Caaguazú are significantly poorer, less educated, and more likely to speak mostly Guaraní, the local indigenous language, than those in Asunción.

\section{Results}

\subsection{Between-List Vote Decisions}

Proposition 2 states that opening the lists should benefit the lists of incumbent parties with candidates over which voters have strong preferences while hurting small parties and reducing abstention (Proposition 1).

In Figure 3, we present the percentage of respondents voting for the Colorado Party (ANR), voting for the Liberal Party (PLRA), voting for the two smaller parties (FG and PDP) grouped together, and abstaining under each system. The top graph presents the results for the control group, the middle graph for first information treatment, and the bottom graph for the second information treatment.

As predicted by Proposition 2, regardless of the information treatment, the Colorado incumbent obtains significantly more votes under the open-list system than in the closed-list system, while the smallest parties FG and PDP get fewer votes. These effects are very large: between 6 and 9 percentage points (depending on the treatment) for the Colorado Party and between 6 and 8 percentage points for the small parties. Consistent with the Liberal Party's candidates being intermediate between those of the Colorado and those of the smallest parties in terms of internal heterogeneity and public exposure, the effects on votes for the

23 Overall, we have 446 households (18\%) for which the survey answers and voting results of both members are available. 
Liberal Party are smaller in size and inconsistent in sign across treatments. Our data also bring some support for Proposition 1: regardless of the information treatment, fewer respondents abstain in the open-list system, but the effect is significant only in the control group.

Clearly, open-lists favor the incumbent party by triggering a transfer of votes from the smallest parties and from previously abstaining voters. To better understand these changes, Figure 4 shows the flows of voters between options across the two electoral systems for the control group. We see that a substantial fraction of voters $(22 \%)$ make different choices across systems. From them, the largest move comes from voters that abstain or vote for small parties in the closed-list system and vote for the larger parties when lists are opened (10\%): only 55\% of voters that abstain or vote for small parties in the closed-list system remain faithful to their option in the open-list system. ${ }^{24}$

To analyze in more detail how vote decisions between lists vary with the electoral system and the provision of information, we estimate a general specification of the following form:

$$
y_{i s}=\alpha+\beta \text { System }^{\text {Open }}+\left(\text { System }^{\text {Open }} * T_{i}^{j}\right)^{\prime} \gamma+\theta_{i}+u_{i s}
$$

where $y_{\text {is }}$ denotes individual $i$ vote decision under system $s=\{$ closed;open $\}$, i.e., the individual choice about the party for which to vote (the two smaller parties FG and PDP are grouped together) or whether to abstain. ${ }^{25}$ System ${ }^{\text {Open }}$ is a dummy variable that takes the value one for the choices under the open-list system, and $T_{i}^{j}$ is a vector of dummy variables for the different informational treatments $j=\{1,2\}$ (with $T^{1}$ being the Treatment Corruption and $T^{2}$ being the Treatment Corruption Social). All specifications include voter-fixed effects

24 This is a remarkable result, as despite a well-documented anchoring effect that may run counter finding any results, in our setting over a fifth of all voters, and over half of those who voted for small parties in the traditional closed-list system, change their behavior when presented with the open-list system.

25 Abstention decisions are treated as an option in its own right. Alternative specifications in which abstention is treated as missing and the sample is restricted to votes for one of the parties yield very similar results (Tables C9 and C10, Appendix C). 
Panel A of Table 1 presents the results from estimating Equation (4). The estimations confirm that in the control group, there is a significant positive effect of the open-list system on participation and on votes for the incumbent (Colorado Party) and to a lesser extent on the votes for the main challenger (Liberal Party). The Colorado Party obtains an additional 6.5 pp. in votes (Column 1), a 13\% increase. On the other hand, small parties lose 6.6 pp. (Column 3), a 28\% decrease, and abstention decreases by 2.3 pp. (Column 4), a $18 \%$ decrease.

Interaction effects between the open-list system and the treatments reveal how the effects above are affected by the provision of information on candidates involved in the Bogado scandal. For the Colorado Party, there is an additional vote-increasing effect of the two treatments, although it is not statistically significant. For the Liberal Party, there is a vote-reducing effect of the Treatment Corruption in the open system, that overcomes the positive effect of opening the lists. For small parties, there is negative effect of the Treatment Corruption Social, which roughly corresponds to the transfer of votes to the Colorado Party.

Proposition 3 states that the magnitude of these effects should be larger among voters possessing a higher level of general political information. To obtain a first evaluation of this prediction, we use the fact that respondents in the urban area of Asunción are significantly richer and more educated than those in Caaguazú (See Table C8), characteristics that are known to correlate positively with better political information. Panels $\mathrm{B}$ and $\mathrm{C}$ of Table 1 present the results from estimating Equation (4) for the Asunción and the Caaguazú samples separately. Consistent with Proposition 3, the estimations show that in the control group, the positive effect of the open-list system on votes for the incumbent (Colorado Party) is larger in Asunción (8.7 pp. in votes (Column 1, Panel B)) than Caaguazú (3.4 pp. in votes (Column 1, Panel C)). Interestingly, opening the lists has a negative and significant impact on abstention in Asunción (6.5 pp. decrease (Column 4, Panel B)) but not in Caaguazú where the sign is reversed (3.6 pp. increase (Column 4, Panel C)).

In Appendix C, Tables C11 to C13 provide further heterogeneous effects 
by interacting the system and the treatment variables with the following voters' characteristics: age, main language spoken, and education. These results confirm that the between-list effect favoring the incumbent Colorado Party is consistently stronger among the more educated, and Spanish-rather than Guaraní-speakers. The most striking results are those related to education and language, which show almost no effect from opening the lists among the less educated and non-Spanish speaking population. The counterintuitive results on abstention in Caaguazú discussed above also appear to be driven by this subset of the population. We therefore find strong support for Proposition 3: only the subset of citizens with better general political information are able to use the additional opportunities offered by the open-list systems.

\subsection{Within-List Vote Decisions}

Our experimental data allow us to explore the validity of the main hypothesis the literature has presented in support of open-list systems: that open electoral rules allow voters to vote against corrupt politicians, especially so in high information environments.

Voters in the open-list system do cross out candidates: on average, Colorado voters cross out 3.77 candidates (std. 2.70) and Liberal voters 3.29 (std. 2.43) candidates. For the smaller parties FG and PDP, the number crossed out are 2.75 and 3.43 , respectively.

In Table 2, we describe how the number of cross-outs varies across voter characteristics for voters who voted for the Colorado incumbent or its main challenger, the Liberal party, in the open-list system. Column 1 shows that the Colorado voters cross out on average 0.5 more candidates than the liberal voters, a significant difference at the $1 \%$ level. Column 2 interacts party choice with the information treatment, finding no significant effect of the information provided. Columns 3 and 4 add individual characteristics. Voters in the Capital Asunción make one additional cross-out on average, while less educated voters make fewer cross-outs, although the effect is only marginally significant. We find no significant effect of interacting individual characteristics with the informa- 
tion treatments. These effects are in line with the heterogeneous effect on vote changes when opening the lists presented in the previous section: urban and more educated voters seem to be able to exploit better the opportunity offered by the open-list system. Finally, Columns 5 and 6 show that individuals who changed their choice when opening the lists ("switchers") do make 0.7 cross-outs more, on average, with this effect being slightly greater for individuals in the social punishment information treatment.

\section{Analysis at the candidate - voter level}

Last, to explore in more detail whether voters punish corrupt candidates, we move to a candidate-voter specification, which allows us to study the determinants of voters' subjective ratings of the candidates. ${ }^{26}$ In this analysis, we include candidates' characteristics (gender, years in office, rank on the party list, presence in the social media), as well as measures of corruption-a dummy indicating whether the candidate was among the 23 senators related to the Bogado immunity scandal ('Involved') and a measure of how the candidate name is related to corruption in the press ('Media Score on Corruption').

We run the following specification:

$$
\text { Cross }_{i j}=\alpha+\beta * \text { Involved }_{j}+\left(X_{j}\right)^{\prime} \delta+\theta_{i}+u_{i j},
$$

where $X_{j}$ are candidates' characteristics and $\theta_{i}$ are voter-fixed effects. We focus on the two main parties and include all the candidates in the experimental ballot. Panel A of Table 3 presents the results for the Colorado Party and Panel B for the Liberal Party.

Column 1 of Table 3 shows that candidates that were involved in the Bogado scandal get crossed out less when from the Colorado Party and more for the Liberal Party while controlling for the candidate being elected (and hence able to participate in the immunity vote). One possible explanation is that Colorado voters do not consider it a bad thing for their senators to protect one of their

26 Figure $\mathrm{C} 1$ shows the share of voters crossing out each candidate, by treatment status of the voters. 
own, while liberal voters clearly resent their elected senators to support immunity for a member of the Colorado party. For the Colorado Party, the negative coefficient on the immunity vote involvement is robust to the inclusion of the additional controls. Column 2 shows that information treatment has no differential impact on this result. ${ }^{27}$ Columns 3 and 4 add candidates characteristics. In Column 4, we include our second measure of corruption, media citation, and we find a positive and significant effect. This points to mixed evidence regarding voters' reaction to corruption involvement since different measures attract different signs. However, it should be noted that these two measures reflect different acts: while the first is related to the immunity Senate vote and hence is not explicitly related to personal embezzlement, the second is related to how the media has related the candidate's name to corruption more generally. For the Liberal Party, the positive sign on involvement in the Bogado scandal (Columns 1 and 2) becomes insignificant when candidate characteristics are included. The alternative measure of corruption, media citations, is also nonsignificant. Regarding candidate characteristics, we see that for both parties, the candidates with more experience and more social media exposure (as measured for having Facebook and/or Twitter accounts) receive more cross-outs.

All results are conditional on controlling for whether a candidate was elected. In column 5 , we show they are unchanged when excluding this control. In particular, there is no shift towards non elected candidates as the result of the information treatment. This indicates that voters' behavior is not the result of the actual 2013 election raising the information about and salience of elected candidates.

In summary, we do not find strong support that voters use the opportunity to cross corrupt candidates when lists are opened. If anything, there seems to be a weak positive correlation between our measure of corruption (being involved in protecting Bogado) and the number of votes for Colorado candidates. This within-list analysis reveals that in this Paraguayan context, voters, especially more educated voters, do use the additional opportunities offered by the open-list

27 This is also robust to including both voters- and candidates-fixed effects. 
system to express preferences over individual candidates. However, corruption does not seem one of the most salient characteristics when choosing which candidates to cross. This is fully consistent with the evidence in Table $\mathrm{C} 2$ : $82 \%$ of respondents who voted for the Colorado Party in the 2013 presidential election consider it to be quite or very corrupt. The equivalent number is $84 \%$ for the Liberal Party, while it decreases to $46 \%$ and $25 \%$, respectively, for the smaller parties FG and the PDP. ${ }^{28}$

In addition, information treatments appear to have very little effect. This is consistent with the fact that a very large fraction of treated voters declare they were already aware of the Bogado scandal (Table B14), and the general belief that all politicians are corrupt (Table B2).

\section{Conclusion}

The standard argument for opening lists in proportional systems is that it is generally desirable to give voters more "control" by designing institutions allowing them to select and punish individual politicians. When electoral institutions formally give them this opportunity, the literature points to information as the main obstacle to exercising this formal control.

In this paper, we propose a model that unveils a thus far neglected adversarial effect of the opening of lists. It highlights that it is likely to favor incumbent corrupt parties, by enhancing the value of their list regardless of the absolute quality of the candidates themselves. Our experimental data largely support this new prediction.

In addition, we question the usual assumption according to which voters would punish corrupt candidates if given the opportunity to do so, by both a

28 The outcome of the 2018 election, run under the status quo closed-list system, provides further evidence that corruption is not a salient characteristic of the candidates whom voters are likely to punish. Together, the Colorado and the Liberal Parties obtained 31 of the 45 Senate seats. Among the 23 Senators who had been involved in the Bogado scandal, 16 were running for reelection, 10 for the Colorado Party and 6 for the Liberal Party. Of these, 9 were reelected, 7 Colorados and 2 Liberals. 
more open electoral system and the provision of relevant information on politicians' behavior. If anything, for the incumbent party, candidates involved in a recent highly publicized corruption scandal seem to receive more votes than other candidates of the same party, and informational treatments have little to no effect.

Combined with earlier work emphasizing other potential adversarial effects of open-list systems, our results cast a negative light on these systems as a tool against corruption. 


\section{References}

Anderson, C. J., \& Tverdova, Y. V. (2003). Corruption, political allegiances, and attitudes toward government in contemporary democracies. American Journal of Political Science, 47(1), 91-109.

Arias, E., Larreguy, H., Marshall, J., \& Querubin, P. (2018). Prior's rule: When do malfeasance revelations help or hurt incumbent parties? NBER Working paper 24888. https://www. nber.org/papers/w24888.

Bagenholm, A. (2013). Throwing the rascals out? the electoral effects of corruption allegations and corruption scandals in europe 19812011. Crime, Law and Social Change, 60(5), 595-609.

Banerjee, A., Kumar, S., Pande, R., \& Su, F. (2011). Do informed voters make better choices? experimental evidence from urban india. Unpublished manuscript. http://scholar.harvard.edu/files/rpande/files/ doinformedvoters_nov11_0.pdf.

Blumenau, J., Eggers, A. C., Hangartner, D., \& Hix, S. (2017). Open/closed list and party choice: Experimental evidence from the uk. British Journal of Political Science, 47(4), 809-827.

Brown, D. S., Touchton, M., \& Whitford, A. (2011). Political polarization as a constraint on corruption: A cross-national comparison. World Development, 39(9), 1516-1529.

Chang, E. C. (2005). Electoral incentives for political corruption under open-list proportional representation. The Journal of Politics, 67(3), 716-730.

Chang, E. C., \& Golden, M. A. (2007). Electoral systems, district magnitude and corruption. British Journal of Political Science, 37(1), 11537.

Chang, E. C., Golden, M. A., \& Hill, S. J. (2010). Legislative malfeasance and political accountability. World Politics, 62(2), 177-220.

Chong, A., De La O, A. L., Karlan, D., \& Wantchekon, L. (2014). Does corruption information inspire the fight or quash the hope? a field experiment in mexico on voter turnout, choice, and party identification. The Journal of Politics, $77(1), 55-71$.

Dunning, T., Grossman, G., Humphreys, M., Hyde, C., Susan D.and McIntosh, 
Nellis, G., Adida, C. L., ... Sircar, N. (2019). Voter information campaigns and political accountability: Cumulative findings from a preregistered meta-analysis of coordinated trials. Science Advances, 5 : eaaw2612, 3895-3962.

Ferraz, C., \& Finan, F. (2008). Exposing corrupt politicians: the effects of brazil's publicly released audits on electoral outcomes. The Quarterly Journal of Economics, 123(2), 703-745.

Finan, F., \& Schechter, L. (2012). Vote-buying and reciprocity. Econometrica, $80(2), 863-881$.

Gonzalez Ocantos, E., de Jonge, C. K., \& Nickerson, D. W. (2014). The conditionality of vote-buying norms: Experimental evidence from latin america. American Journal of Political Science, 58(1), 197-211.

Kselman, D. (2011). Electoral institutions and political corruption: Ballot structure, electoral formula and graft. Political Economy of Institutions, Democracy, and Voting, 327-371.

Kunicova, J., \& Rose-Ackerman, S. (2005). Electoral rules and constitutional structures as constraints on corruption. British Journal of Political Science, 35(4), 573-606.

Lagunes, P. F. (2012). Corruption's challenge to democracy: a review of the issues. Politics \& Policy, 40(5), 802-826.

McCann, J., \& Dominguez, J. (1998). Mexicans react to electoral fraud and political corruption: An assessment of public opinion and voting behavior. Electoral Studies, 17, 483-503.

Melo, M. A., Pereira, C., \& Figueiredo, C. M. (2009). Political and institutional checks on corruption: Explaining the performance of brazilian audit institutions. Comparative Political Studies, 42(9), 1217-1244.

Nyblade, B., \& Reed, S. R. (2008). Who cheats? who loots? political competition and corruption in japan, 19471993. American Journal of Political Science, 52(4), 926-941.

Olken, B. A., \& Pande, R. (2012). Corruption in developing countries. Annual Review of Economics, 4(1), 479-509.

Persson, T., \& Tabellini, G. (2000). Political economics: Explaining economic 
policy. MIT press.

Persson, T., Tabellini, G., \& Trebbi, F. (2003). Electoral rules and corruption. Journal of the European Economic Association, 1(4), 958-89.

Peters, J. G., \& Welch, S. (1980). The effects of charges of corruption on voting behavior in congressional elections. The American Political Science Review, 74, 697-708.

Potter, J., \& Tavits, M. (2012). Curbing corruption with political institutions. International Handbook on the Economics of Corruption. S. Rose-Ackerman and T. Soreide (Eds.), 2, 52-79.

Rose-Ackerman, S. (1999). Corruption and government: Causes, consequences, and reform. Cambridge University Press.

Rose-Ackerman, S. (2005). Political corruption and reform in democracies: theoretical perspectives. In Comparing political corruption and clientelism, ed. junichi kawata (pp. 65-82). Routledge.

Schleiter, P., \& Voznaya, A. (2014). Party system competitiveness and corruption. Party Politics, 20(5), 675-686.

Seligson, M. A. (2002). The impact of corruption on regime legitimacy: A comparative study of four latin american countries. The Journal of Politics, $64,408-433$.

Serra, D. (2006). Empirical determinants of corruption: A sensitivity analysis. Public Choice, 126, 225-256.

Stephenson, M. C. (2015). Corruption and democratic institutions: a review and synthesis. Greed, Corruption, and the Modern State: Essays in Political Economy. Susan Rose-Ackerman \& Paul Lagunes, eds., 92-133.

Straub, S. (2014). Political firms, public procurement, and the democratization process. TSE Working paper(14-461). https://www.tse-fr.eu/sites/ default/files/medias/doc/wp/dev/wp_tse_461.pdf.

Straub, S. (2015). The story of paraguayan dams: the long-term consequences of wrongdoing in procurement. Greed, Corruption, and the Modern State: Essays in Political Economy, 161.

Tavits, M. (2007). Clarity of responsibility and corruption. American Journal of Political Science, 51(1), 218-229. 
Winters, M. S., \& Weitz-Shapiro, R. (2012). Lacking information or condoning corruption: When will voters support corrupt politicians? Journal of Comparative Politics, 45(4), 418-436. 


\begin{tabular}{cccc}
$\begin{array}{c}\text { National } \\
\text { election }\end{array}$ & $\begin{array}{c}\text { Senate vote } \\
\text { on Bogado }\end{array}$ & $\begin{array}{c}\text { Our } \\
\text { experiment }\end{array}$ & $\begin{array}{c}\text { Next National } \\
\text { Election }\end{array}$ \\
\hline 21 April & $\begin{array}{c}14 \text { Nov. } \\
2013\end{array}$ & $\begin{array}{c}\text { April-June } \\
2015\end{array}$ & $\begin{array}{c}\text { April } \\
2013\end{array}$ \\
\hline 2013
\end{tabular}

Figure 1: Timing

The figure shows the timing of events. The national election of April 2013 was followed by the Bogado scandal. The social movement following the Senate vote on Nov. 2013 are the events presented in our information treatment. Our experiment was performed approximately one year after the end of the protests. 


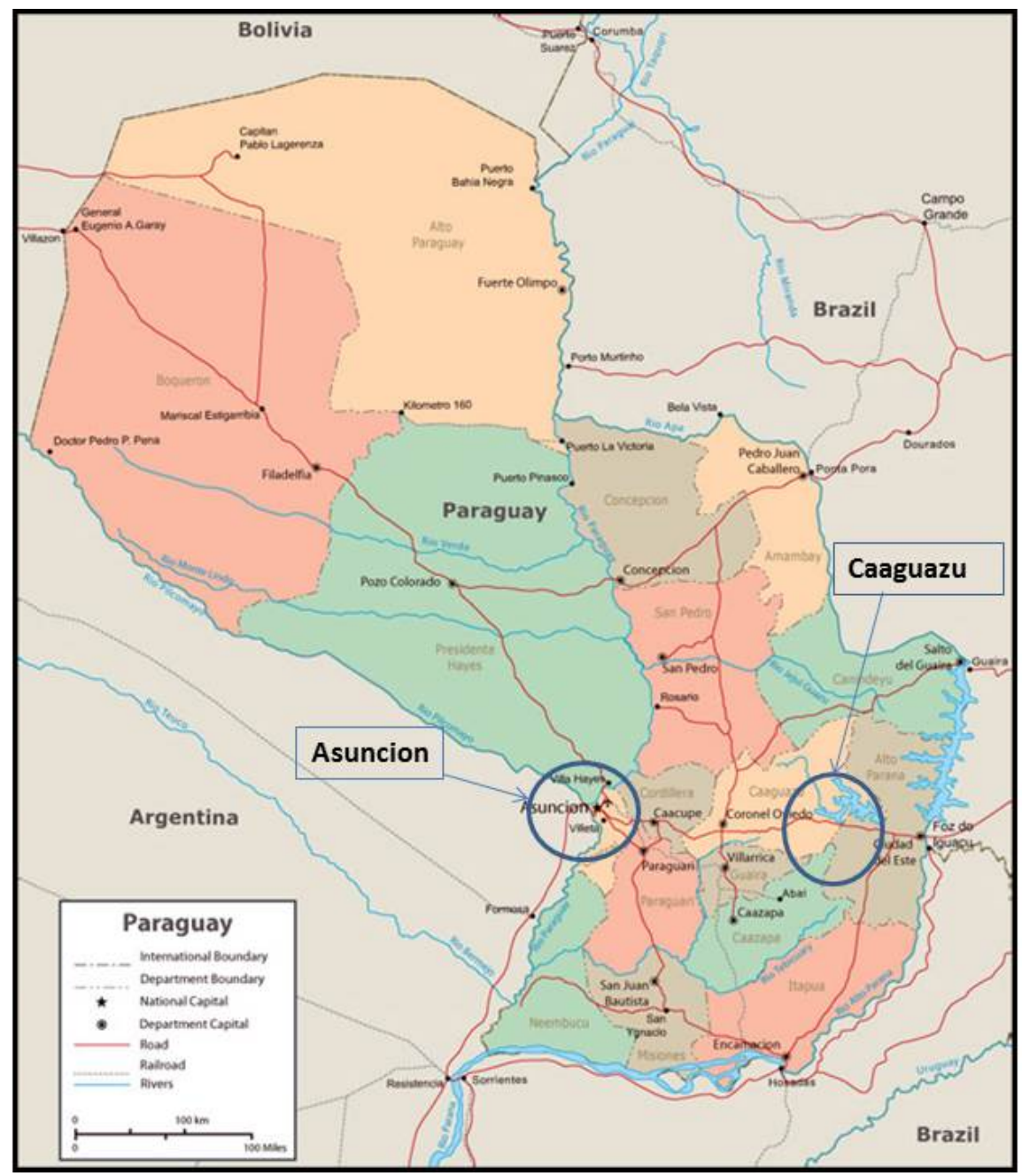

Figure 2: Map of the experimental regions.

The map shows the two regions where the experiment was performed, the capital city Asunción (1547 participants) and the rural area of Caaguazú (1094 participants). 

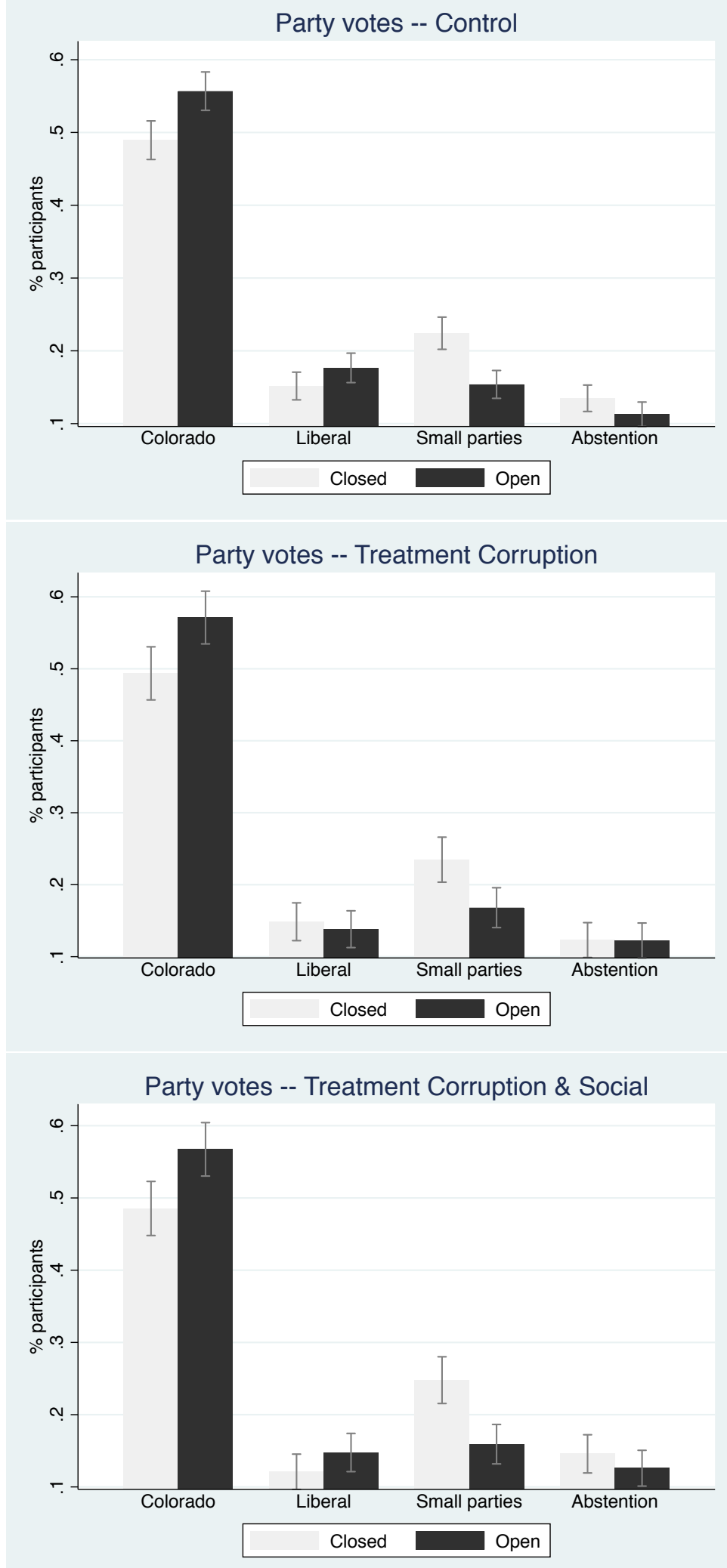

Figure 3: Party votes under alternative electoral systems - By treatment groups. The figure presents the percentages of respondents voting for the Colorado (ANR) Party, the Liberal (PLRA) Party, and the small (FG and PDP) parties and abstaining in the closed- and open-list system. The bars represent $95 \%$ confidence intervals. 


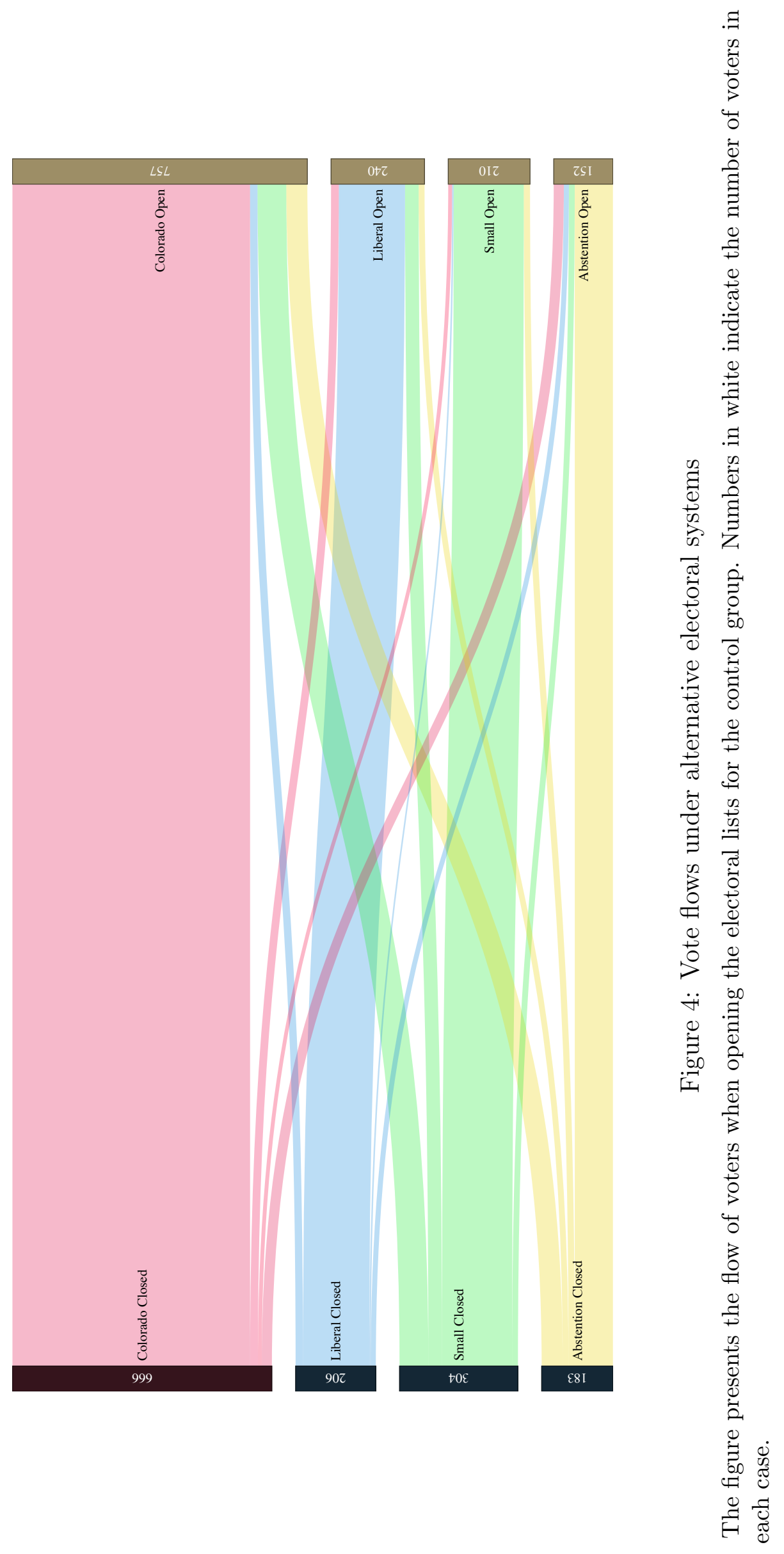


Table 1: Between-Parties Vote Decisions

\begin{tabular}{|c|c|c|c|c|}
\hline \multicolumn{5}{|c|}{ Panel A: Whole Sample } \\
\hline & Colorado & Liberal & Small parties & Abstention \\
\hline & (1) & $(2)$ & $(3)$ & $(4)$ \\
\hline Open system & $\begin{array}{c}0.0648^{* * *} \\
(0.011)\end{array}$ & $\begin{array}{c}0.0250^{* * *} \\
(0.007)\end{array}$ & $\begin{array}{c}-0.0664^{* * *} \\
(0.009)\end{array}$ & $\begin{array}{c}-0.0234^{* * *} \\
(0.009)\end{array}$ \\
\hline Open*TC & $\begin{array}{l}0.0208 \\
(0.018)\end{array}$ & $\begin{array}{c}-0.0326^{* * *} \\
(0.012)\end{array}$ & $\begin{array}{c}-0.0085 \\
(0.016)\end{array}$ & $\begin{array}{l}0.0204 \\
(0.015)\end{array}$ \\
\hline Open*TCS & $\begin{array}{l}0.0146 \\
(0.018)\end{array}$ & $\begin{array}{l}0.0062 \\
(0.013)\end{array}$ & $\begin{array}{c}-0.0286^{*} \\
(0.016)\end{array}$ & $\begin{array}{l}0.0079 \\
(0.015)\end{array}$ \\
\hline Constant & $\begin{array}{c}0.4923^{* * *} \\
(0.005)\end{array}$ & $\begin{array}{c}0.1411^{* * *} \\
(0.004)\end{array}$ & $\begin{array}{c}0.2352^{* * *} \\
(0.005)\end{array}$ & $\begin{array}{c}0.1314^{* * *} \\
(0.004)\end{array}$ \\
\hline Observations & 5,185 & 5,185 & 5,185 & 5,185 \\
\hline Number of voters & 2,609 & 2,609 & 2,609 & 2,609 \\
\hline R-squared & 0.038 & 0.008 & 0.050 & 0.003 \\
\hline \multicolumn{5}{|c|}{ Panel B: Asunción } \\
\hline & Colorado & Liberal & Small parties & Abstention \\
\hline & (1) & $(2)$ & (3) & $(4)$ \\
\hline Open system & $\begin{array}{c}0.0867^{* * *} \\
(0.014)\end{array}$ & $\begin{array}{c}0.0373^{* * *} \\
(0.009)\end{array}$ & $\begin{array}{c}-0.0587^{* * *} \\
(0.012)\end{array}$ & $\begin{array}{c}-0.0653^{* * *} \\
(0.011)\end{array}$ \\
\hline Open*TC & $\begin{array}{l}0.0028 \\
(0.025)\end{array}$ & $\begin{array}{c}-0.0505^{* * *} \\
(0.015)\end{array}$ & $\begin{array}{l}0.0087 \\
(0.021)\end{array}$ & $\begin{array}{c}0.0390^{* *} \\
(0.018)\end{array}$ \\
\hline Open*TCS & $\begin{array}{l}0.0144 \\
(0.025)\end{array}$ & $\begin{array}{r}-0.0001 \\
(0.015)\end{array}$ & $\begin{array}{c}-0.0424^{* *} \\
(0.021)\end{array}$ & $\begin{array}{c}0.0281+ \\
(0.018)\end{array}$ \\
\hline $\begin{array}{l}\text { Constant } \\
(0.007)\end{array}$ & $\begin{array}{c}0.5085^{* * *} \\
(0.004)\end{array}$ & $\begin{array}{c}0.1167^{* * *} \\
(0.006)\end{array}$ & $\begin{array}{c}0.2179^{* * *} \\
(0.005)\end{array}$ & $0.1568^{* * *}$ \\
\hline Observations & 3,031 & 3,031 & 3,031 & 3,031 \\
\hline Number of voters & 1,525 & 1,525 & 1,525 & 1,525 \\
\hline R-squared & 0.847 & 0.869 & 0.823 & 0.821 \\
\hline \multicolumn{5}{|c|}{ Panel C: Caaguazú } \\
\hline & Colorado & Liberal & Small parties & Abstention \\
\hline & (1) & $(2)$ & (3) & $(4)$ \\
\hline Open system & $\begin{array}{c}0.0340^{* *} \\
(0.015)\end{array}$ & $\begin{array}{l}0.0075 \\
(0.012)\end{array}$ & $\begin{array}{c}-0.0774^{* * *} \\
(0.015)\end{array}$ & $\begin{array}{c}0.0358^{* *} \\
(0.015)\end{array}$ \\
\hline Open*TC & $\begin{array}{c}0.0463^{*} \\
(0.026)\end{array}$ & $\begin{array}{r}-0.0075 \\
(0.021)\end{array}$ & $\begin{array}{r}-0.0321 \\
(0.026)\end{array}$ & $\begin{array}{l}-0.0067 \\
(0.026)\end{array}$ \\
\hline Open*TCS & $\begin{array}{l}0.0149 \\
(0.027)\end{array}$ & $\begin{array}{l}0.0150 \\
(0.021)\end{array}$ & $\begin{array}{r}-0.0091 \\
(0.026)\end{array}$ & $\begin{array}{l}-0.0208 \\
(0.026)\end{array}$ \\
\hline Constant & $\begin{array}{c}0.4696^{* * *} \\
(0.008) \\
\end{array}$ & $\begin{array}{c}0.1754^{* * *} \\
(0.006)\end{array}$ & $\begin{array}{c}0.2594^{* * *} \\
(0.007)\end{array}$ & $\begin{array}{c}0.0955^{* * *} \\
(0.007)\end{array}$ \\
\hline Observations & 2,154 & 2,154 & 2,154 & 2,154 \\
\hline Number of voters & 1,084 & 1,084 & 1,084 & 1,084 \\
\hline R-squared & 0.876 & 0.868 & 0.828 & 0.697 \\
\hline
\end{tabular}


Table 2: Within-list vote decisions: Number of cross-outs by voter

\begin{tabular}{|c|c|c|c|c|c|c|}
\hline & (1) & (2) & (3) & (4) & (5) & (6) \\
\hline Vote for Colorado & $\begin{array}{c}0.4758^{* * *} \\
(0.155)\end{array}$ & $\begin{array}{c}0.5072^{* *} \\
(0.212)\end{array}$ & $\begin{array}{c}0.3297^{* *} \\
(0.126)\end{array}$ & $\begin{array}{c}0.3227^{* *} \\
(0.123)\end{array}$ & $\begin{array}{c}0.5319 * * * \\
(0.168)\end{array}$ & $\begin{array}{c}0.5341^{* * *} \\
(0.170)\end{array}$ \\
\hline $\mathrm{TC}$ & & $\begin{array}{r}-0.1022 \\
(0.184)\end{array}$ & & & & \\
\hline TCS & & $\begin{array}{c}-0.0622 \\
(0.106)\end{array}$ & & & & \\
\hline TC * Colorado & & $\begin{array}{l}0.1925 \\
(0.281)\end{array}$ & & & & \\
\hline TCS * Liberal & & $\begin{array}{l}0.3253 \\
(0.240)\end{array}$ & & & & \\
\hline Age over mean & & & $\begin{array}{c}-0.1162 \\
(0.135)\end{array}$ & $\begin{array}{c}-0.2076 \\
(0.190)\end{array}$ & & \\
\hline Guarani speaker & & & $\begin{array}{r}-0.1846 \\
(0.189)\end{array}$ & $\begin{array}{r}-0.2592 \\
(0.249)\end{array}$ & & \\
\hline Asuncion & & & $\begin{array}{c}1.1585^{* * *} * \\
(0.159)\end{array}$ & $\begin{array}{c}1.1103^{* * *} \\
(0.246)\end{array}$ & & \\
\hline Low education & & & $\begin{array}{c}-0.3119+ \\
(0.194)\end{array}$ & $\begin{array}{r}-0.2328 \\
(0.198)\end{array}$ & & \\
\hline $\mathrm{TC} *$ Age & & & & $\begin{array}{c}0.0456 \\
(0.197)\end{array}$ & & \\
\hline TCS * Age & & & & $\begin{array}{l}0.3012 \\
(0.348)\end{array}$ & & \\
\hline $\mathrm{TC} *$ Guarani & & & & $\begin{array}{l}0.1268 \\
(0.336)\end{array}$ & & \\
\hline TCS * Guarani & & & & $\begin{array}{l}0.1479 \\
(0.355)\end{array}$ & & \\
\hline Info $\mathrm{C}^{*}$ Asuncion & & & & $\begin{array}{l}0.2346 \\
(0.348)\end{array}$ & & \\
\hline TCS * Asuncion & & & & $\begin{array}{c}-0.0623 \\
(0.273)\end{array}$ & & \\
\hline TC $*$ Less educated & & & & $\begin{array}{l}-0.2371 \\
(0.237)\end{array}$ & & \\
\hline TCS $*$ Less educated & & & & $\begin{array}{r}-0.1187 \\
(0.213)\end{array}$ & & \\
\hline Switcher & & & & & $\begin{array}{c}0.7613^{* *} \\
(0.311)\end{array}$ & $\begin{array}{c}0.6484^{*} \\
(0.300)\end{array}$ \\
\hline TC $*$ Switcher & & & & & & $\begin{array}{c}-0.0800 \\
(0.442)\end{array}$ \\
\hline TCS * Switcher & & & & & & $\begin{array}{c}0.5122+ \\
(0.325)\end{array}$ \\
\hline Constant & $\begin{array}{c}3.2968^{* * *} \\
(0.285)\end{array}$ & $\begin{array}{c}3.2578^{* * *} \\
(0.335)\end{array}$ & $\begin{array}{c}3.0324^{* * *} \\
(0.274)\end{array}$ & $\begin{array}{c}3.0529 * * * \\
(0.278)\end{array}$ & $\begin{array}{c}3.0894^{* * *} \\
(0.248)\end{array}$ & $\begin{array}{c}3.0958^{* * * *} \\
(0.249)\end{array}$ \\
\hline Observations & 1,880 & 1,880 & 1,880 & 1,880 & 1,880 & 1,880 \\
\hline R-squared & 0.005 & 0.006 & 0.069 & 0.071 & 0.019 & 0.021 \\
\hline
\end{tabular}

Notes: Robust standard errors in parentheses. ${ }^{* * *} \mathrm{p}<0.01,{ }^{* *} \mathrm{p}<0.05,{ }^{*} \mathrm{p}<0.1,+\mathrm{p}<0.15$. The unit of observation is a voter, and the dependent variable corresponds to the number of candidates the voter crossed out. The sample is restricted to voters voting for the two main parties (Colorado and Liberal) under open-lists. A switcher is defined as a voter who votes for different options in the different voting systems presented. 
Table 3: Within-list vote decisions: Voter-candidate analysis

\begin{tabular}{|c|c|c|c|c|c|}
\hline & (1) & $(2)$ & (3) & (4) & (5) \\
\hline \multicolumn{6}{|l|}{ Panel A: Colorado Party } \\
\hline Elected candidate & $\begin{array}{c}0.1561^{* * *} \\
(0.005)\end{array}$ & $\begin{array}{c}0.1561^{* * *} \\
(0.005)\end{array}$ & $\begin{array}{c}-0.0683^{* * *} \\
(0.008)\end{array}$ & $\begin{array}{c}-0.0575^{* * *} \\
(0.008)\end{array}$ & \\
\hline Involved in Bogado immunity vote & $\begin{array}{c}-0.0806^{* * *} \\
(0.004)\end{array}$ & $\begin{array}{c}-0.0874^{* * *} \\
(0.006)\end{array}$ & $\begin{array}{c}-0.0492^{* * *} \\
(0.004)\end{array}$ & $\begin{array}{c}-0.0800 * * * \\
(0.004)\end{array}$ & $\begin{array}{c}-0.0866 * * * \\
(0.004)\end{array}$ \\
\hline TC * Involved & & $\begin{array}{l}0.0133 \\
(0.010)\end{array}$ & & & \\
\hline TCS * Involved & & $\begin{array}{l}0.0132 \\
(0.010)\end{array}$ & & & \\
\hline Gender (female) & & & $\begin{array}{c}-0.0543^{* * *} \\
(0.008)\end{array}$ & $\begin{array}{c}0.0250^{* * *} \\
(0.008)\end{array}$ & $\begin{array}{c}0.0308^{* * *} \\
(0.008)\end{array}$ \\
\hline Years in congress & & & $\begin{array}{c}0.0120^{* * *} \\
(0.000)\end{array}$ & $\begin{array}{c}0.0119 * * * \\
(0.000)\end{array}$ & $\begin{array}{c}0.0111^{* * *} \\
(0.000)\end{array}$ \\
\hline Rank in party list & & & $\begin{array}{c}-0.0009^{*} \\
(0.001)\end{array}$ & $\begin{array}{c}-0.0049^{* * *} \\
(0.001)\end{array}$ & $\begin{array}{c}-0.0033^{* * *} \\
(0.000)\end{array}$ \\
\hline Facebook & & & $\begin{array}{c}0.1174^{* * *} \\
(0.005)\end{array}$ & $\begin{array}{c}0.0416^{* * *} \\
(0.005)\end{array}$ & $\begin{array}{c}0.0420^{* * *} \\
(0.005)\end{array}$ \\
\hline Twitter & & & $\begin{array}{c}0.2032^{* * *} \\
(0.005)\end{array}$ & $\begin{array}{c}0.1032^{* * *} \\
(0.005)\end{array}$ & $\begin{array}{c}0.0910^{* * *} \\
(0.005)\end{array}$ \\
\hline Media score on corruption & & & & $\begin{array}{c}0.0674^{* * *} \\
(0.002) \\
\end{array}$ & $\begin{array}{c}0.0679^{* * *} \\
(0.002) \\
\end{array}$ \\
\hline Observations & 31,060 & 31,060 & 31,060 & 31,060 & 31,060 \\
\hline R-squared & 0.140 & 0.140 & 0.233 & 0.260 & 0.259 \\
\hline \multicolumn{6}{|l|}{ Panel B: Liberal Party } \\
\hline Elected candidate & $\begin{array}{c}0.0434^{* * *} \\
(0.010)\end{array}$ & $\begin{array}{c}0.0434^{* * *} \\
(0.010)\end{array}$ & $\begin{array}{c}-0.0546^{* *} \\
(0.026)\end{array}$ & $\begin{array}{c}-0.0496^{*} \\
(0.027)\end{array}$ & \\
\hline Involved in Bogado immunity vote & $\begin{array}{c}0.1152^{* * *} \\
(0.011)\end{array}$ & $\begin{array}{c}0.1066^{* * *} \\
(0.015)\end{array}$ & $\begin{array}{c}0.0203^{*} \\
(0.012)\end{array}$ & $\begin{array}{l}0.0190 \\
(0.012)\end{array}$ & $\begin{array}{l}0.0195 \\
(0.012)\end{array}$ \\
\hline $\mathrm{TC} *$ Involved & & $\begin{array}{c}0.0098 \\
(0.023)\end{array}$ & & & \\
\hline TCS * Involved & & $\begin{array}{c}0.0279 \\
(0.024)\end{array}$ & & & \\
\hline Gender (female) & & & $\begin{array}{c}-0.0333^{* * *} \\
(0.007)\end{array}$ & $\begin{array}{c}-0.0309^{* * *} \\
(0.007)\end{array}$ & $\begin{array}{c}-0.0296^{* * *} \\
(0.007)\end{array}$ \\
\hline Years in congress & & & $\begin{array}{c}0.0052^{* * *} \\
(0.001)\end{array}$ & $\begin{array}{c}0.0054^{* * *} * \\
(0.001)\end{array}$ & $\begin{array}{c}0.0064 * * * \\
(0.001)\end{array}$ \\
\hline Rank in party list & & & $\begin{array}{c}-0.0087^{* * *} * \\
(0.002)\end{array}$ & $\begin{array}{c}-0.0085^{* * *} \\
(0.002)\end{array}$ & $\begin{array}{c}-0.0090 * * * \\
(0.002)\end{array}$ \\
\hline Facebook & & & $\begin{array}{c}0.0652^{* *} \\
(0.033)\end{array}$ & $\begin{array}{c}0.0575^{*} \\
(0.034)\end{array}$ & $\begin{array}{l}-0.106 \\
(0.015)\end{array}$ \\
\hline Twitter & & & $\begin{array}{c}0.0156^{*} \\
(0.008)\end{array}$ & $\begin{array}{c}0.0173^{* *} \\
(0.008)\end{array}$ & $\begin{array}{c}0.0246^{* * *} \\
(0.008)\end{array}$ \\
\hline Media score on corruption & & & & $\begin{array}{l}0.0051 \\
(0.009)\end{array}$ & $\begin{array}{l}0.0112 \\
(0.009)\end{array}$ \\
\hline Observations & 8,800 & 8,800 & 8,800 & 8,800 & 8,800 \\
\hline R-squared & 0.143 & 0.144 & 0.178 & 0.178 & 0.177 \\
\hline
\end{tabular}




\section{Appendix A - Theoretical Framework: Discus- sion and Extensions}

In this appendix, we discuss general features of open-list systems and propose a formal derivation of the updating of voters' subjective evaluations of the candidates to disentangle more clearly the role played by the a priori heterogeneity of the lists and the general information about the candidates.

Voting systems: The main formal difference between closed- and open-list PR systems lies in how much power voters are given to decide who gets elected within a list. In a closed-list system, voters face party lists, each presenting a set of preordered candidates. The ranking of the candidates on the list is determined by the party. Each voter votes for one of these party lists or abstains. Vote shares determine how many seats each party gets. Within each list, the rank of the candidates determines whether they are elected or not. In such a system, voters have no direct control over which candidates within the lists are elected. The only thing voters control is how many candidates get elected within each list.

In open-list systems, each voter votes for one party or abstains, and vote shares determine how many seats each party gets, as in the closed-list system. But voters can also (to some extent) determine which candidates within the list are elected by additionally casting votes for individual candidates. There is a wide variety of open-list systems in practice, which differ in the rules determining how these votes for individual candidates can be cast. In particular, there are some variations in the maximal number of candidate votes a voter is allowed to cast: one (e.g., Sweden and Denmark), some fixed number larger than one (e.g., post-WWII Italy, where the maximum number of votes was three or four), or even no limit (e.g., Latvia). Open-list systems also differ in how much votes over candidates can overrule any pre-ordering of the candidates fixed by the parties.

In our survey, respondents are asked to vote under a closed-list system, and under an open-list system in which they can vote for any number of candidates on the list without any constraint. We will therefore study this case in the theory 
section.

Assumptions about voters' information: Consider list $l$. Denote by $x_{c}^{l}$ the "true" value of candidate $c$ for the voter. It is the value she would assign to this candidate, were she is perfectly informed. In a situation where she is only imperfectly informed about the characteristics and the history of the candidates, we assume that the voter will form some expectations about the value of these candidates based on two types of information: (i) the party a candidate belongs to and (ii) some candidate-specific information she might have gathered in the past.

Let us start with the former. We assume that the voter's a priori beliefs on the candidates' values from list $l$ follow i.i.d. normal distribution with mean 0 and standard deviation $s^{l}$. The distribution of these a priori beliefs are the same for all candidates in the party. It summarizes the general information the voter has about this party. We will interpret $s^{l}$ as the a priori heterogeneity in the party. For example, a large party that is well known to encompass a large variety of ideological views will have a large $s^{l}$, whereas a party which mainly focuses on one single issue will have a low $s^{l}$.

Apart from this general information about the party, the voter also has the opportunity to learn some specific information about the candidates on the list. It might be obtained through the electoral campaign, because some candidates have already served in the government or in past legislatures, or because they have been exposed in the media for whatever reason (including some corruption scandals). We will capture this candidate-specific information by assuming that the voter receives a signal $y_{c}^{l}$ that is informative about the value to her of candidate $c$. More specifically, we will assume that $y_{c}^{l}=x_{c}^{l}+\epsilon_{c}^{l}$, where $\epsilon_{c}^{l}$ is normally distributed with mean 0 and standard error $\sigma_{c}^{l}$ (the $\epsilon_{c}^{l}$ are assumed to be independently distributed across candidates). The smaller $\sigma_{c}^{l}$ is, the higher the quality of this candidate-specific signal. Note that we allow for the informativeness of the signals to vary with the candidates. Indeed, within the same list, some candidates might have served longer terms in the past or have received more exposure in the media than others. 
Under these assumptions, given her general information about the party and conditional on the candidate-specific signal $y_{c}^{l}$, the voter updates her beliefs about the value of candidate $c$, and at the time of the vote, the expected rating is as follows:

$$
q_{c}^{l}=\frac{\left(s^{l}\right)^{2}}{\left(s^{l}\right)^{2}+\left(\sigma_{c}^{l}\right)^{2}} * y_{c}^{l} .
$$

The updated value $q_{c}^{l}$ is a convex combination of the prior (0) and the signal $\left(y_{c}^{l}\right)$. If $\sigma_{c}^{l} \rightarrow+\infty$ (no further information about the candidates), the updated value coincides with the prior (0), and if $\sigma_{c}^{l} \rightarrow 0$ (perfect information about the candidates), the updated value coincides with the signal, which itself coincides with the candidate value $\left(x_{c}^{l}\right)$.

Votes under closed-list and open-list systems: In the closed-list system, if a voter votes for a list, she passively votes for all the candidates on the list. In contrast, in the open-list system, the best choice is to actively vote only for candidates with a positive (expected) ratings $\left(q_{c}^{l}\right)$. The difference between the maximal utility a voter can derive from voting for list $l$ under the openlist system and the utility she derives from voting for this same list under the closed-list system is given by formula (3) in the main text. Substituting for the expression of $q_{c}^{l}$ given in (A1), one obtains the following:

$$
U_{\text {open }}^{l *}-U_{\text {closed }}^{l}=\sum_{c}\left(\frac{\left(s^{l}\right)^{2}}{\left(s^{l}\right)^{2}+\left(\sigma_{c}^{l}\right)^{2}} *\left(\Psi^{+} * \max \left[y_{c}^{l}, 0\right]-\Psi^{-} * \min \left[y_{c}^{l}, 0\right]\right)\right)>0 .
$$

Expression (A2) confirms that whatever the true quality of the candidates and whatever the signals, participation should be higher under the open-list system than under the closed-list system.

Comparative statics: To derive some comparative statics with respect to the a priory heterogeneity of the list $\left(s^{l}\right)$ and the precision of the signal of the candidates' quality $\left(1 /\left(\sigma_{c}^{l}\right)^{2}\right)$, we compute the ex ante expectation of quantity (A2). Note that at this ex ante stage, $y_{c}^{l}=x_{c}^{l}+\epsilon_{c}^{l}$ is normally distributed with 
mean 0 and variance $\left(s^{l}\right)^{2}+\left(\sigma_{c}^{l}\right)^{2}$. Noting that

$$
E\left[\max \left(y_{c}^{l}, 0\right)\right]=\frac{\sqrt{\left.\left(s^{l}\right)^{2}+\left(\sigma_{c}^{l}\right)^{2}\right)}}{\sqrt{2 \pi}}=-E\left[\min \left(y_{c}^{l}, 0\right)\right]
$$

one obtains that, in expectation, the difference in utility of voting for a given list under open- and closed-list systems, denoted $\Delta U$, is

$$
\Delta U=\frac{\Psi^{-}+\Psi^{+}}{\sqrt{2 \pi}} * \sum_{c} \frac{\left(s^{l}\right)^{2}}{\sqrt{\left(s^{l}\right)^{2}+\left(\sigma_{c}^{l}\right)^{2}}} .
$$

Computing the partial derivatives yields the following:

$$
\begin{gathered}
\frac{\partial(\Delta U)}{\partial\left(\left(s^{l}\right)^{2}\right)}=\frac{\Psi^{-}+\Psi^{+}}{2 \sqrt{2 \pi}} * \sum_{c} \frac{\left(s^{l}\right)^{2}+2\left(\sigma_{c}^{l}\right)^{2}}{\left(\left(s^{l}\right)^{2}+\left(\sigma_{c}^{l}\right)^{2}\right)^{3 / 2}}>0, \\
\frac{\partial(\Delta U)}{\partial\left(\sigma_{c}^{l}\right)^{2}}=-\frac{\Psi^{-}+\Psi^{+}}{2 \sqrt{2 \pi}} * \sum_{c} \frac{\left(s^{l}\right)^{2}}{\left(\left(s^{l}\right)^{2}+\left(\sigma_{c}^{l}\right)^{2}\right)^{3 / 2}}<0, \\
\frac{\partial^{2}(\Delta U)}{\partial\left(\left(s^{l}\right)^{2}\right) \partial\left(\sigma_{c}^{l}\right)^{2}}=\frac{\Psi^{-}+\Psi^{+}}{4 \sqrt{2 \pi}} * \sum_{c} \frac{\left(s^{l}\right)^{2}-2\left(\sigma_{c}^{l}\right)^{2}}{\left(\left(s^{l}\right)^{2}+\left(\sigma_{c}^{l}\right)^{2}\right)^{5 / 2}} .
\end{gathered}
$$

we can now state the following claim:

Claim: In expectation, the difference in utility of voting for a given list under open- and closed-list systems increases with a priori heterogeneity of the list $\left(\left(s^{l}\right)^{2}\right)$ and with the precision of the signals on the candidates $\left(1 /\left(\sigma_{c}^{l}\right)^{2}\right)$.

This claim provides support for our main predictions. Indeed, the incumbent party is characterized by a presumably large a priori diversity and good information on candidates. It should be the list that benefits the most from opening the lists. In contrast, the small parties are a priori less diverse, and voters have poor information on their candidates. In relative terms, they should lose from opening the lists (Proposition 2). Furthermore, the difference in utility of voting for a given list under open- and closed-list systems is increasing with the voter's information about the candidates. The effects of opening the lists are expected to be larger in magnitude among well-informed voters (Proposition 3). 


\section{Appendix B - Experimental Materials}

Voting was always done with the participant alone in the room, standing apart from the interviewer, to allow for privacy. Here is the transcript of how the systems were presented to the participants. This presentation was preceded by a reminder of the academic nature of the activity, of the guarantee of confidentiality, and of the right of the participant not to answer a question and/or stop the questionnaire. The interviewers had a Guarani translation to ensure homogeneity of the explanation provided across languages.

1. In the current system in Paraguay, the following holds:

(a) Each voter votes for the list of a political party. Each party obtains a number of seats in the Senate proportional to the number of votes obtained, and

(b) Given the number of seats of each party, the candidates to the Senate enter in the order indicated by the party on the electoral list.

Please look with attention at the form I am showing you. In it, you can see the four principal parties that participated in the Senate elections on April 21, 2013.

Please vote, marking on the form your choice (one of the parties or abstention). When you have made your choice, please fold the form and place it in the envelope.

2. There has been a debate in Paraguay about the possibility of opening the electoral lists. The idea is to reform the electoral system so that voters can not only vote for a party but also express their opinion on the candidates inside the party lists.

Imagine the voting system was as follows:

(a) Each voter votes for the list of a political party. Each party obtains a number of seats in the Senate proportional to the number of votes obtained, and 
(b) When the voter chooses a party list, he/she can also cross out one or more names of candidates that he/she wants to take out of the list.

In this system, to cross out one or more candidates' names does not change anything for the party, which obtains the same number of seats in the Senate. The only thing the system does is to take the crossed-out candidates down the list and take the ones that were not crossed-out up the list.

We now ask you to proceed to vote with this system. In the form I am handing to you, you should first mark the party you want to vote for or for abstention. Once you have marked the list you want to vote for, you can cross out one or more candidates' names inside this list.

When you have made your choice, please fold the form and place it in the envelope. 


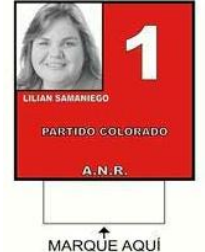

Lilian G. Samanieg

Luis A. Castiglioni

Arnoldo Wiens

Mirta L. Gusinky

Julio Cesar Velazquez

Oscar Gonzalez Daher

Gustavo J. Alfonso

Enrique F. Bacchetta

Silvio A. Ovelar

Julio A. Quiñonez

Juan Carlos Galaverna

Derlis A. Osorio

Blanca Ovelar

Mario Abdo Benitez

Oscar R. Salomon

Juan Dario Monges

Victor A. Bogado

Nelson D. Aguinagalde

Carlos Nuñez

Oscar Campuzano

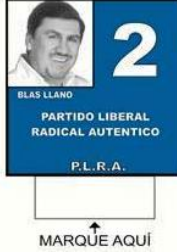

las A. Llano

Emilia P. Alfaro

Ramon Gomez

Carlos A. Amarilla

Zulma R. Gomez

Enzo Cardozo

Julio Cesar Franco

Luis A. Wagner

Blanca B. Fonseca

Miguel Abdon Saguier

Fernando A. Silva

Maria Mignarro

Roberto R. Acevedo

Francisco J. Rivas

Corina Gonzalez

Modesto L. Guggiari

Silvio Nunez

Nelson Segovia

Ruffino Palmerola

Gloria Escobar

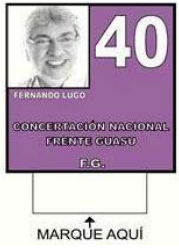

Fernando A. Lugo

Carlos A. Filizzola

Sixto Pereira

Esperanza Martinez

Oscar H. Richer

Belarmino Balbuena

Victor Bareiro

Juan De Dios Acosta

Celsa Ramirez

Jose Parra

Ernesto Benitez

Alberto R. Alderete

Carmen Sanchez

Saturnino O. Ruiz

Ceferino O. Sostoa

Adolfo G. Gimenez

Estanislao Barreto

Juan Carlos Ayala

Francisco Garcia

Pedro B. Espinoza

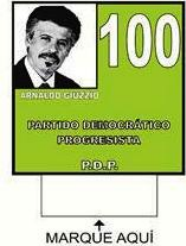

MAROU E

Desiree G. Masi

Pedro Santa Cruz

Alcides D. Wood

Jorgelina Candia

Sixto R. Escobar

Gladys Santa Cruz

Ricardo A. Lugo

Gloria E. Granado

Ramon A. Caballero

Dilia Z. Albawi

Alba L. Cabrera

Ricardo E. Morales

Blanca Ayala

Celina Vera

Felix A. Valdez

Celsa Quiñonez

Eduardo Chenu

Antonio Alfonzo

Jose Alcaraz Salcedo

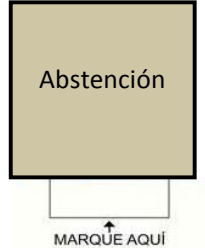

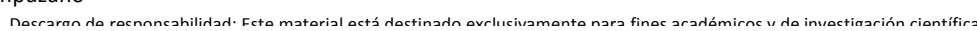

Figure B1: Voting form - Closed-list.

CANDIDATOS A SENADORES DE LA NACIÓN

MARCAR CON BOLIGRAFO DENTRO DEL RECUADRO LA CANDIDATURA DE SU PREFERENCIA
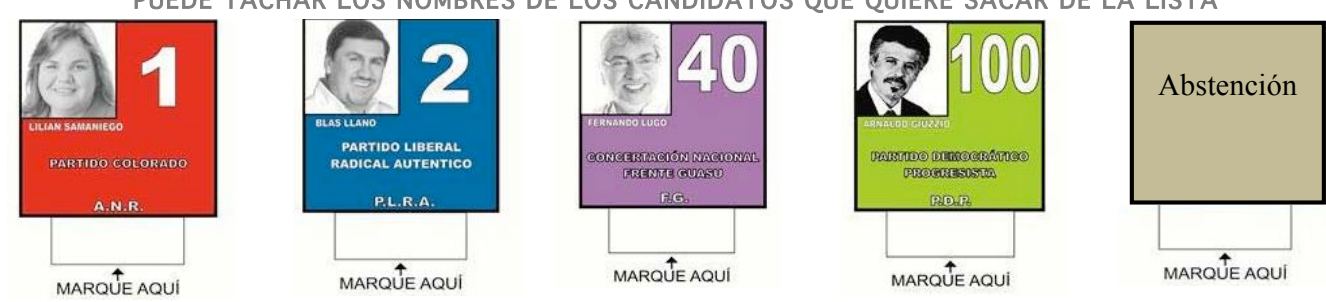

BLAS A. LLANO

EMILIA P. Alfaro

RAMON GomeZ

CARLos A. AMarilla

ZuLMA R. GomeZ

Enzo CARDozo
Julio CeSAR Franco

Julio Cesar Franco

LUIS A. WAGNER

BLANCA B. FONSECA

Miguel ABDON SAGU

FERNANDO A. SILVA

MARIA MIGNARRO

FRANCISCO J RIVAS

FRANCISCO J. RIVAS

CORINA GONZALEZ

SiLvio NunEz

SEGOVIA

Ruffino Palmerol

Fernando A. Lugo

Carlos A. Filizzo

SIXTO PEREIRA

ESPERANZA MARTINEZ

OSCAR H. RICHER

BELARMINO BALBUEN

VICTOR BAREIRO

Juan De Dios Acosta

CELSA RAMIREZ

JOSE PARRA

ERNESTO BENITEZ

ALBERTO R. ALDERE

CARMEN SANCHEZ

SATURNINO O. RUIZ

CEREIN O.SOSTOA

ADOLFO G. GIMENEZ

Jun C

FRANCISCO GaRCIA

MARQUE AQU

ARnAlDo E. GiuzZ

DESIREE G. MASI

PEdRo SANTA CRUZ

ALCIDES D. WOOD

JORGELINA CANDIA

SIXTO R. EsCOBAR

GLADS SANTA CRUZ

RICARDO A. LUGO

GLORIA E. GRANADO

RAMON A. CABALL

DILIA Z. ALBAWI

ALBA L. CABRERA

RICARDO E. MORALE

BLANCA AYLA

CELINA VERA

CELSA QUIÑONEZ

CELSA QUINONEZ

ANTONO ALFONZ

ANTONIO ALFONZO

CAnsos

Descargo de responsabilidad: Este material está destinado exclusivamente para fines académicos y de investigación científica. M2

Figure B2: Voting form - Open-list. 
Figure B3: Information booklet, pages 1 and 2 .

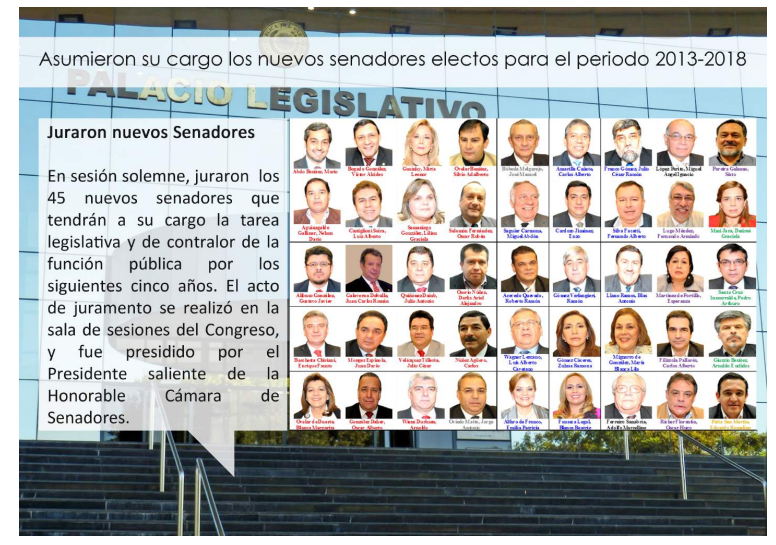

Figure B4: Information booklet: control group.

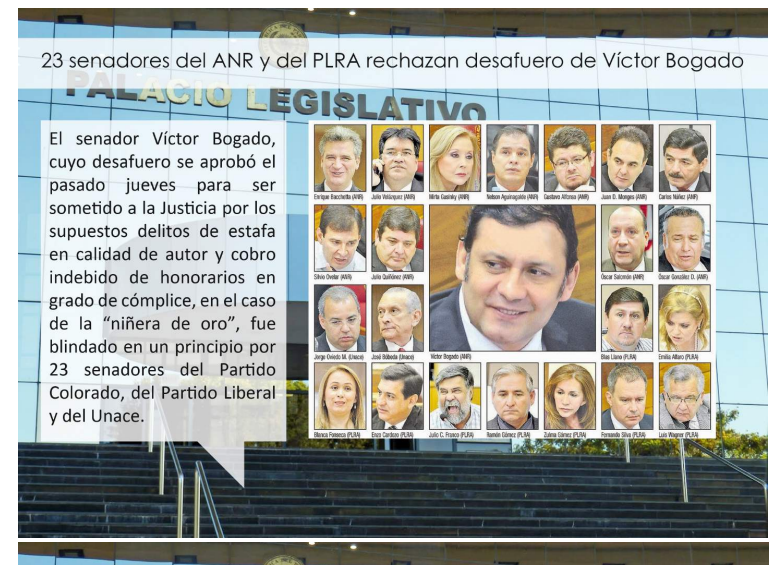

Comercios escrachan a senadores que rechazaron desafuero de Víctor Bogado

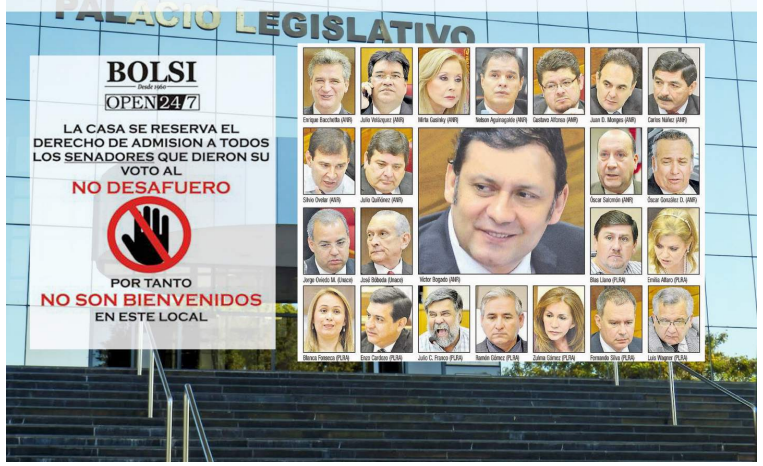

Figure B5: Information booklet: information treatments. 


\section{Appendix C - Descriptive Statistics and Addi- tional Results}

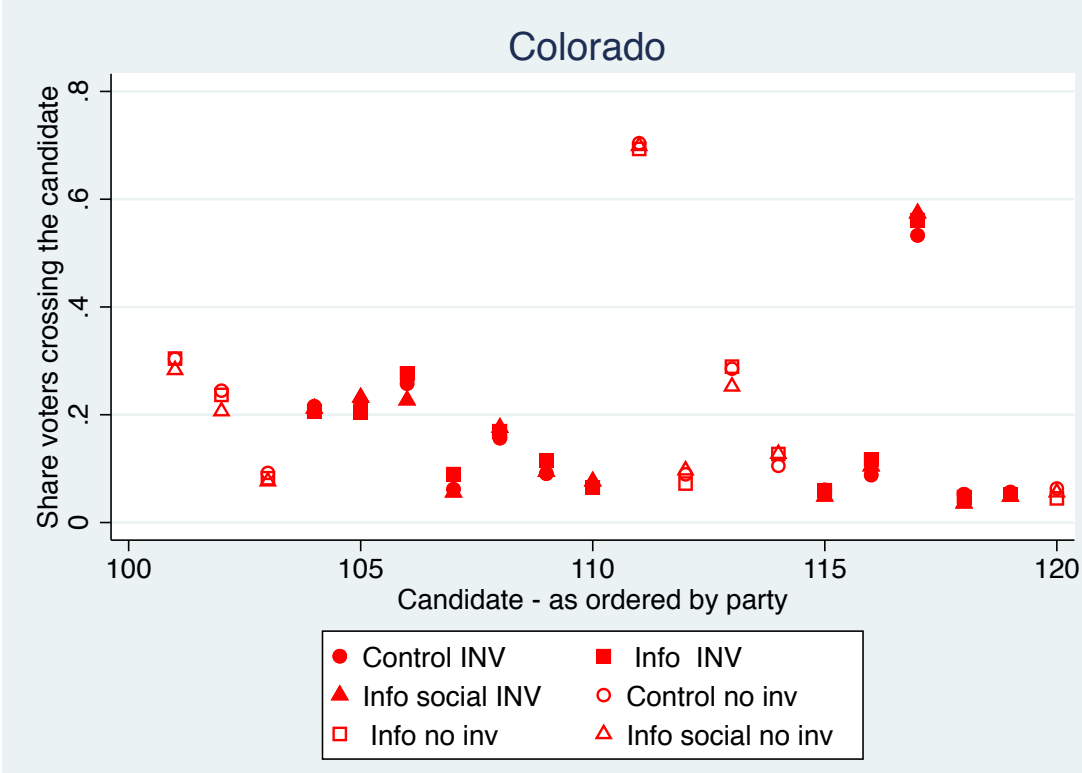

Liberal

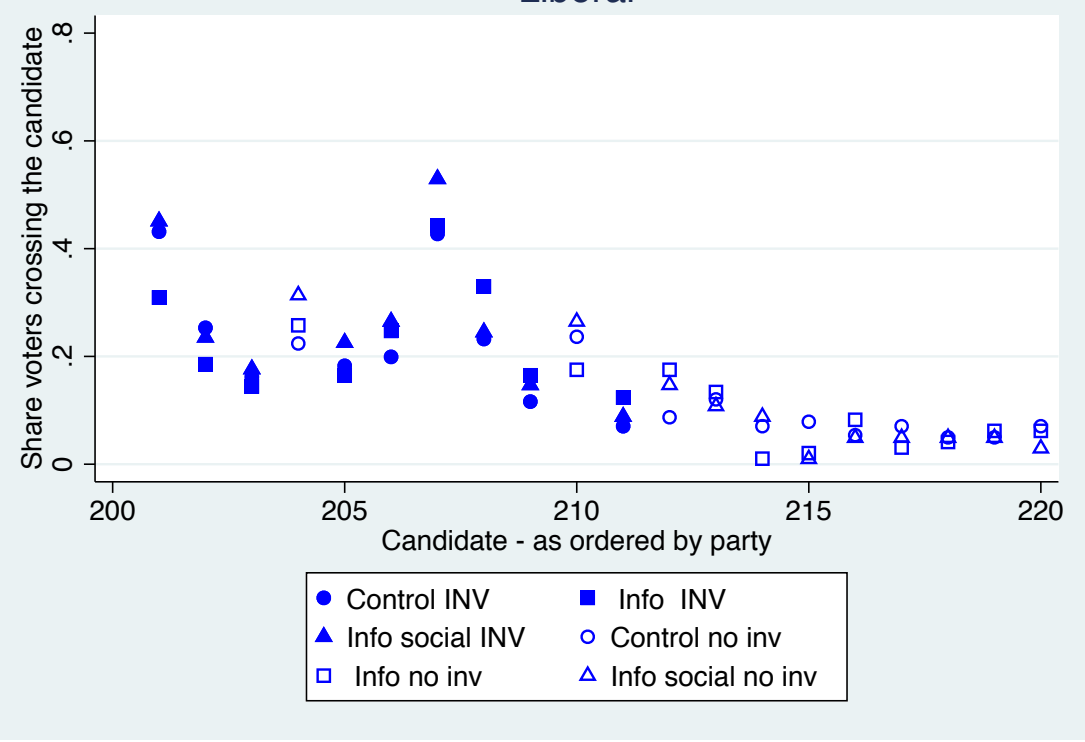

Figure C1: Share of voters crossing each candidate

The figure presents the share of voters crossing out each of the candidates for the Colorado-ANR and Liberal-PLRA Parties. Control, Info, and Info Social correspond to the different treatment arms. INV (resp. No inv) indicates candidates who were (resp. were not) involved in the Bogado immunity vote. In the upper panel, the two outliers are Victor Bogado-candidate 17 on the Colorado list-and Juan Carlos Galaverna-candidate 11, who had faced a sex tape scandal in the months before the experiment took place. 
Table C1: Corruption

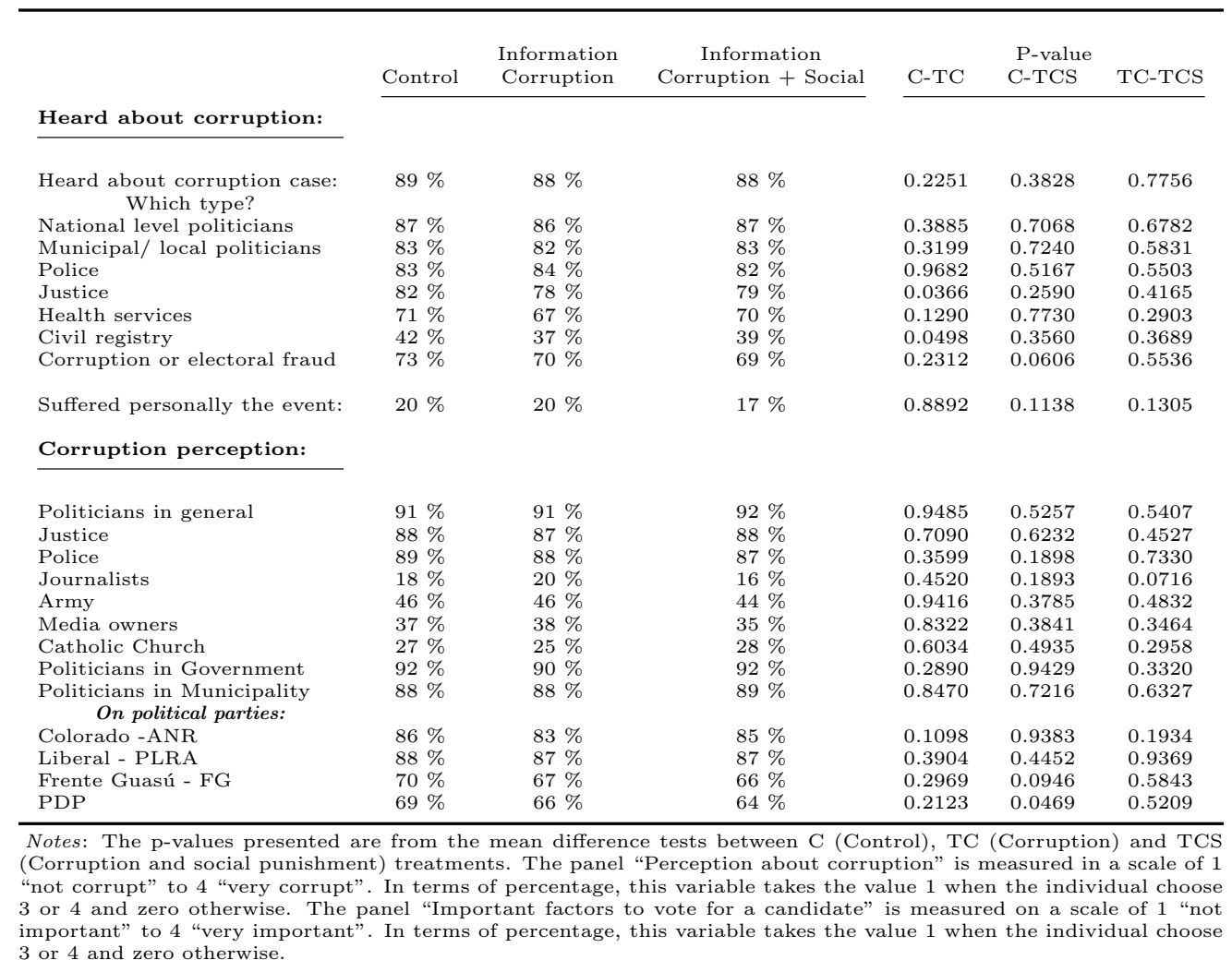

Table C2: Perception on political corruption

\begin{tabular}{lccccc}
\hline & & Colorado-ANR & Liberal-PLRA & FG & PDP \\
\cline { 3 - 6 } & & $(1)$ & $(2)$ & $(3)$ & $(4)$ \\
\multirow{3}{*}{ Vote 2013} & & & & \\
& & & $90 \%$ & $76 \%$ & $73 \%$ \\
& Colorado-ANR & $82 \%$ & $84 \%$ & $64 \%$ & $64 \%$ \\
& Liberal-PLRA & $94 \%$ & $96 \%$ & $46 \%$ & $53 \%$ \\
& FG & $96 \%$ & $92 \%$ & $58 \%$ & $25 \%$ \\
\hline & PDP & $77 \%$ & 467 & 154 & 13 \\
\hline
\end{tabular}

Notes: The table presents voters' corruption perception for the different parties as a function of what they declare to have voted for in the 2013 presidential election. Vote 2013 refers to the vote in the 2013 Presidential election as stated by respondents. The perception of corruption is measured on a scale of 1 "not corrupt" to 4 "very corrupt". To translate in percentages, this variable takes the value one when the individual choose 3 or 4 and zero otherwise. The variable Total number of votes presents the votes per party as declared in the sample for the presidential election of 2013. 
Table C3: Links to political parties

\begin{tabular}{|c|c|c|c|c|c|c|}
\hline & Control & $\begin{array}{l}\text { Treatment } \\
\text { Corruption }\end{array}$ & $\begin{array}{c}\text { Treatment } \\
\text { Corruption Social }\end{array}$ & C-TC & $\begin{array}{l}\text { P-value } \\
\text { C-TCS }\end{array}$ & TC-TCS \\
\hline Affiliated Colorado -ANR & $65 \%$ & $66 \%$ & $66 \%$ & 0.4655 & 0.5156 & 0.9491 \\
\hline Affiliated Liberal - PLRA & $21 \%$ & $20 \%$ & $20 \%$ & 0.6449 & 0.5673 & 0.9194 \\
\hline Affiliated Small Parties & $1 \%$ & $1 \%$ & $1 \%$ & 0.2880 & 0.4994 & 0.7163 \\
\hline Total affiliated to a party & $86 \%$ & $86 \%$ & $86 \%$ & 0.8582 & 0.9644 & 0.9078 \\
\hline Identified with Colorado - ANR & $32 \%$ & $29 \%$ & $31 \%$ & 0.2172 & 0.4917 & 0.6367 \\
\hline Identified with Liberal - PLRA & $12 \%$ & $10 \%$ & $9 \%$ & 0.1642 & 0.0768 & 0.7261 \\
\hline Identified with Small Parties & $3 \%$ & $4 \%$ & $3 \%$ & 0.6860 & 0.9629 & 0.6981 \\
\hline Total identified with a party & $47 \%$ & $43 \%$ & $43 \%$ & 0.0606 & 0.0774 & 0.9317 \\
\hline Contributed money to the party: & $4 \%$ & $3 \%$ & $4 \%$ & 0.2075 & 0.8427 & 0.1966 \\
\hline \multicolumn{7}{|c|}{ Important factors to vote for a candidate } \\
\hline Party Family tradition & $47 \%$ & $48 \%$ & $46 \%$ & 0.6128 & 0.7637 & 0.4837 \\
\hline Will improve health system & $90 \%$ & $91 \%$ & $90 \%$ & 0.7133 & 0.7807 & 0.5744 \\
\hline Will improve schools & $91 \%$ & $92 \%$ & $91 \%$ & 0.6331 & 0.7582 & 0.4944 \\
\hline Will give me a job & $60 \%$ & $59 \%$ & $57 \%$ & 0.7254 & 0.1998 & 0.4173 \\
\hline Will give money if I vote for him & $7 \%$ & $8 \%$ & $5 \%$ & 0.1378 & 0.3504 & 0.0376 \\
\hline Will improve job opportunities & $90 \%$ & $90 \%$ & $89 \%$ & 0.7235 & 0.6312 & 0.4692 \\
\hline Is religious & $44 \%$ & $44 \%$ & $46 \%$ & 0.8095 & 0.5039 & 0.4289 \\
\hline \multicolumn{7}{|l|}{ Vote in 2013 presidential election } \\
\hline Voted Colorado - ANR in 2013 & $59 \%$ & $60 \%$ & $59 \%$ & 0.6277 & 0.8831 & 0.7702 \\
\hline Voted Liberal - PLRA in 2013 & $19 \%$ & $18 \%$ & $20 \%$ & 0.6613 & 0.6286 & 0.4231 \\
\hline Voted FG or PDP in 2013 & $4 \%$ & $6 \%$ & $5 \%$ & 0.1890 & 0.5826 & 0.5212 \\
\hline
\end{tabular}


Table C4: Candidates characteristics

\begin{tabular}{|c|c|c|c|c|}
\hline & Mean & $\mathrm{Sd}$ & Max & Min \\
\hline \multicolumn{5}{|l|}{ Total sample } \\
\hline Gender & $22 \%$ & 0.422 & 1 & 0 \\
\hline New in senate & $31 \%$ & 0.467 & 1 & 0 \\
\hline Years in congress & 7.78 & 6.694 & 22 & 0 \\
\hline Elected & $80 \%$ & 0.405 & 1 & 0 \\
\hline Exposed & $53 \%$ & 0.506 & 1 & 0 \\
\hline Facebook & $78 \%$ & 0.417 & 1 & 0 \\
\hline Twitter & $45 \%$ & 0.504 & 1 & 0 \\
\hline $\mathrm{ABC}($ Name $)$ & 3,179 & 3,525 & 14,325 & 0 \\
\hline ABC (Name + corruption) & 450 & 1,599 & 9779 & 0 \\
\hline \multicolumn{5}{|l|}{ Colorado } \\
\hline Gender & $15 \%$ & 0.366 & 1 & 0 \\
\hline New in senate & $40 \%$ & 0.503 & 1 & 0 \\
\hline Years in congress & 7 & 6.704 & 22 & 0 \\
\hline Elected & $95 \%$ & 0.224 & 1 & 0 \\
\hline Involved & $60 \%$ & 0.503 & 1 & 0 \\
\hline Facebook & $80 \%$ & 0.410 & 1 & 0 \\
\hline Twitter & $45 \%$ & 0.510 & 1 & 0 \\
\hline $\mathrm{ABC}($ Name) & 3,662 & 3,795 & 14,325 & 36 \\
\hline ABC (Name + corruption) & 262 & 499 & 2269 & 7 \\
\hline \multicolumn{5}{|l|}{ Liberal } \\
\hline Gender & $31 \%$ & 0.479 & 1 & 0 \\
\hline New in senate & $19 \%$ & 0.403 & 1 & 0 \\
\hline Years in congress & 9 & 6.768 & 22 & 0 \\
\hline Elected & $65 \%$ & 0.489 & 1 & 0 \\
\hline Involved & $45 \%$ & 0.510 & 1 & 0 \\
\hline Facebook & $76 \%$ & 0.437 & 1 & 0 \\
\hline Twitter & $45 \%$ & 0.510 & 1 & 0 \\
\hline $\mathrm{ABC}($ Name) & 2,643 & 3,221 & 12,702 & 0 \\
\hline ABC (Name + corruption) & 658 & 2,280 & 9779 & 0 \\
\hline
\end{tabular}

Notes: The variable ABC (Name) refers to the number of times the candidates was mentioned in the website of the newspaper $A B C$. The variable $\mathrm{ABC}$ (Name+Corruption) refers to the number of times the candidate was mentioned in topics of corruption in the website of the newspaper $A B C$. Gender is a dummy that takes the value of 1 when the candidate is a woman. The variables Facebook and Twitter represent the percentage of candidates using these social networking sites. The variable Exposed is a dummy that takes the value of 1 if that candidate was involved in the Bogado voting scandal presented in the experiment. 
Table C5: Candidates characteristics by involvement in Bogado's case

\begin{tabular}{|c|c|c|c|c|c|}
\hline \multirow[b]{2}{*}{ Variable } & \multicolumn{2}{|c|}{$\begin{array}{c}(1) \\
\text { Not involved }\end{array}$} & \multicolumn{2}{|c|}{$\begin{array}{c}(2) \\
\text { Involved }\end{array}$} & \multirow{2}{*}{$\begin{array}{c}\text { T-test } \\
\text { Difference } \\
(1)-(2)\end{array}$} \\
\hline & $\mathrm{N}$ & Mean/SE & $\mathrm{N}$ & Mean/SE & \\
\hline Gender $(1=\mathrm{F}, 0=\mathrm{M})$ & 19 & $\begin{array}{c}0.263 \\
(0.104)\end{array}$ & 21 & $\begin{array}{c}0.190 \\
(0.088)\end{array}$ & 0.073 \\
\hline New in Senate $(1=$ yes $0=$ no $)$ & 19 & $\begin{array}{c}0.421 \\
(0.116)\end{array}$ & 21 & $\begin{array}{c}0.143 \\
(0.078)\end{array}$ & $0.278^{*}$ \\
\hline Years in congress & 19 & $\begin{array}{l}5.105 \\
(1.651)\end{array}$ & 21 & $\begin{array}{c}8.714 \\
(1.313)\end{array}$ & $-3.609^{*}$ \\
\hline Rank & 19 & $\begin{array}{l}12.316 \\
(1.370)\end{array}$ & 21 & $\begin{array}{c}8.857 \\
(1.164)\end{array}$ & $3.459^{*}$ \\
\hline ABC corruption & 19 & $\begin{array}{l}-0.321 \\
(0.099)\end{array}$ & 21 & $\begin{array}{c}0.291 \\
(0.276)\end{array}$ & $-0.612^{*}$ \\
\hline Facebook & 19 & $\begin{array}{c}0.526 \\
(0.118)\end{array}$ & 21 & $\begin{array}{c}0.905 \\
(0.066)\end{array}$ & $-0.378^{* * *}$ \\
\hline Twitter & 19 & $\begin{array}{c}0.474 \\
(0.118)\end{array}$ & 21 & $\begin{array}{c}0.429 \\
(0.111)\end{array}$ & 0.045 \\
\hline \multirow{2}{*}{\multicolumn{5}{|c|}{$\begin{array}{l}\text { F-test of joint significance (F-stat) } \\
\text { F-test, number of observations }\end{array}$}} & $3.121^{* *}$ \\
\hline & & & & & 40 \\
\hline
\end{tabular}

Notes: The value displayed for t-tests are the differences in the means across the groups. The value displayed for $\mathrm{F}$-tests are the $\mathrm{F}$-statistics. ${ }^{* * *}$, ${ }^{* *}$, and ${ }^{*}$ indicate significance at the 1,5, and 10 percent levels. The table presents the comparison of the candidate characteristics for the two main parties by whether they were involved in the Bogado scandal senate immunity vote. The variable rank denotes the position of the candidate in the party's ballot. ABC corruption is an index of the exposure of the candidate in the ABC newspaper. We use a count of these mentions between June 30, 2013, which is the date the new legislature took office, and March 30, 2015, the end of the month immediately before our experimental roll-out. 


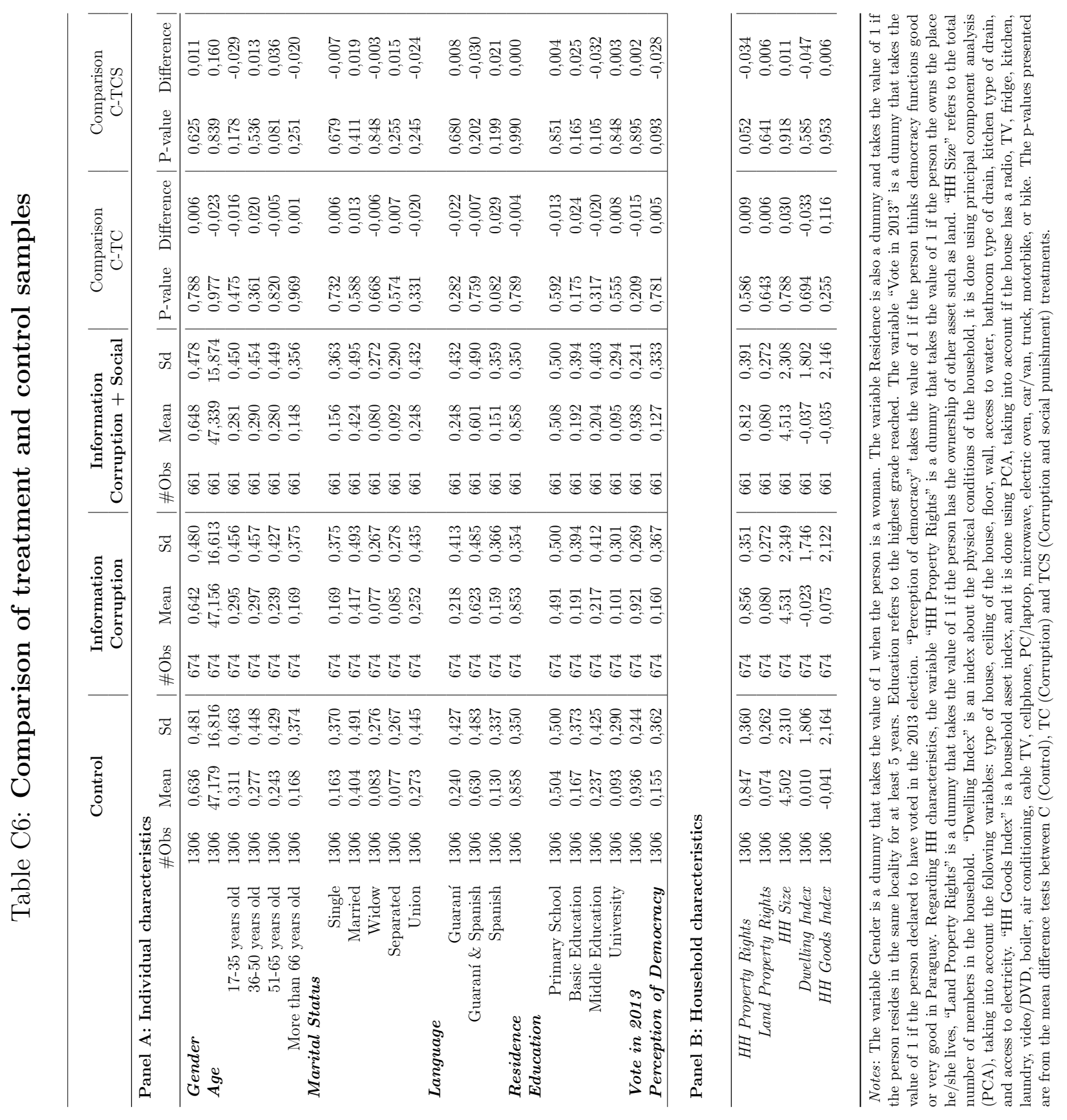


Table C7: Sample representativeness

\begin{tabular}{|c|c|c|c|c|}
\hline & \multicolumn{2}{|c|}{ Caaguazú } & \multicolumn{2}{|c|}{ Asunción } \\
\hline & Sample & $2015 E P H$ & Sample & $2015 E P H$ \\
\hline \multicolumn{5}{|c|}{ Individual characteristics } \\
\hline Gender & $67.28 \%$ & $53.00 \%$ & $61.80 \%$ & $50.00 \%$ \\
\hline \multicolumn{5}{|l|}{ Education } \\
\hline Primary School & $71.76 \%$ & $68.81 \%$ & $34.91 \%$ & $32.80 \%$ \\
\hline Basic Education & $14.53 \%$ & $12.73 \%$ & $20.36 \%$ & $29.26 \%$ \\
\hline Middle Education & $9.60 \%$ & $12.69 \%$ & $31.35 \%$ & $36.58 \%$ \\
\hline University & $4.11 \%$ & & $13.38 \%$ & \\
\hline \multicolumn{5}{|c|}{ Household characteristics } \\
\hline HH Property Rights & $89.58 \%$ & $87.34 \%$ & $80.16 \%$ & $69.14 \%$ \\
\hline House connected to water & $64.00 \%$ & $68.94 \%$ & $99.00 \%$ & $99.00 \%$ \\
\hline Radio & $80.62 \%$ & $74.65 \%$ & $94.31 \%$ & $86.6 \%$ \\
\hline TV & $92.69 \%$ & $87.35 \%$ & $98.38 \%$ & $97.7 \%$ \\
\hline Fridge & $82.54 \%$ & $82.56 \%$ & $96.25 \%$ & $94.2 \%$ \\
\hline Kitchen & $63.53 \%$ & $50.39 \%$ & $93.67 \%$ & $84.4 \%$ \\
\hline Laundry & $70.20 \%$ & $69.03 \%$ & $82.74 \%$ & $80.9 \%$ \\
\hline Video/DVD & $25.05 \%$ & $20.61 \%$ & $52.17 \%$ & $49.2 \%$ \\
\hline Air Conditioning & $11.43 \%$ & $13.54 \%$ & $53.72 \%$ & $50.9 \%$ \\
\hline TV Cable & $18.01 \%$ & $27.39 \%$ & $51.65 \%$ & $62.4 \%$ \\
\hline Cellphone & $84.37 \%$ & $87.55 \%$ & $83.65 \%$ & $95.6 \%$ \\
\hline Computer/Laptop & $18.28 \%$ & $13.54 \%$ & $52.42 \%$ & $50.9 \%$ \\
\hline Electric Oven & $29.71 \%$ & $35.74 \%$ & $57.01 \%$ & $51.5 \%$ \\
\hline Motorbike & $66.54 \%$ & $69.25 \%$ & $31.03 \%$ & $20.8 \%$ \\
\hline
\end{tabular}

Education and health services

\section{Health Insurance}

$\begin{array}{rrrrr}\text { IPS } & 12.36 \% & 12.19 \% & 39.24 \% & 31.95 \% \\ \text { No insurance } & 84.89 \% & 85.66 \% & 51.52 \% & 43.36 \%\end{array}$

Type of school

\begin{tabular}{rrrrr} 
Public & $96.50 \%$ & $95.18 \%$ & $68.71 \%$ & $43.07 \%$ \\
Private & $3.50 \%$ & $4.82 \%$ & $17.52 \%$ & $37.46 \%$ \\
Subsidized & & & $12.80 \%$ & $19.47 \%$ \\
\hline
\end{tabular}

Notes: This table provide a comparison of the experimental sample with the national household survey (EPH: Encuesta Permanente de Hogares 2015). The variable Gender is a dummy that takes the value of 1 when the person is a woman. Regarding HH characteristics, the variable "HH Property Rights" is a dummy that takes the value of 1 if the person has the ownership of the place he/she lives, and "House connected to water" takes the value of 1 when the house is connected to local water system. On Health Insurance, IPS is a dummy that takes value 1 if the person is covered by the Instituto Paraguayo de Salud. Type of school refers to the education center of the children in the $\mathrm{HH}$, if any. 
Table C8: Comparison of Asunción and Caaguazú samples

Panel A: Individual characteristics

\begin{tabular}{|c|c|c|c|c|c|c|c|c|}
\hline & \multicolumn{3}{|c|}{ Caaguazú } & \multicolumn{3}{|c|}{ Asunción } & \multicolumn{2}{|c|}{ Comparison } \\
\hline & $\# O b s$ & Mean & $S d$ & $\# O b s$ & Mean & $S d$ & $P$-value & Difference \\
\hline Gender & 1094 & 0.673 & 0.469 & 1547 & 0.618 & 0.486 & 0.004 & 0.055 \\
\hline Age & 1094 & 45.279 & 16.182 & 1547 & 48.581 & 16.636 & 0.000 & -3.302 \\
\hline $17-35$ years old & 1094 & 0.331 & 0.471 & 1547 & 0.277 & 0.448 & 0.003 & 0.054 \\
\hline $36-50$ years old & 1094 & 0.305 & 0.461 & 1547 & 0.271 & 0.445 & 0.058 & 0.034 \\
\hline $51-65$ years old & 1094 & 0.227 & 0.419 & 1547 & 0.269 & 0.444 & 0.014 & -0.042 \\
\hline $\begin{array}{l}\text { More than } 66 \text { years old } \\
\text { Marital Status }\end{array}$ & 1094 & 0.137 & 0.344 & 1547 & 0.182 & 0.386 & 0.002 & -0.045 \\
\hline Single & 1094 & 0.141 & 0.348 & 1547 & 0.178 & 0.383 & 0.010 & -0.038 \\
\hline Married & 1094 & 0.454 & 0.498 & 1547 & 0.383 & 0.486 & 0.000 & 0.072 \\
\hline Widow & 1094 & 0.065 & 0.246 & 1547 & 0.092 & 0.289 & 0.012 & -0.027 \\
\hline Separated & 1094 & 0.071 & 0.257 & 1547 & 0.091 & 0.288 & 0.069 & -0.020 \\
\hline Union & 1094 & 0.269 & 0.444 & 1547 & 0.256 & 0.437 & 0.462 & 0.013 \\
\hline Language & & & & & & & & \\
\hline Guaraní & 1094 & 0.467 & 0.499 & 1547 & 0.073 & 0.260 & 0.000 & 0.394 \\
\hline Guaraní \& Spanish & 1094 & 0.514 & 0.500 & 1547 & 0.697 & 0.460 & 0.000 & -0.183 \\
\hline Spanish & 1094 & 0.019 & 0.137 & 1547 & 0.230 & 0.421 & 0.000 & -0.211 \\
\hline $\begin{array}{l}\text { Residence } \\
\text { Education }\end{array}$ & 1094 & 0.829 & 0.377 & 1547 & 0.876 & 0.330 & 0.001 & -0.047 \\
\hline Primary School & 1094 & 0.718 & 0.450 & 1547 & 0.349 & 0.477 & 0.000 & 0.368 \\
\hline Basic Education & 1094 & 0.145 & 0.353 & 1547 & 0.204 & 0.403 & 0.000 & -0.058 \\
\hline Middle Education & 1094 & 0.096 & 0.295 & 1547 & 0.314 & 0.464 & 0.000 & -0.218 \\
\hline University & 1094 & 0.041 & 0.199 & 1547 & 0.134 & 0.341 & 0.000 & -0.093 \\
\hline Vote in 2013 & 1094 & 0.872 & 0.334 & 1547 & 0.976 & 0.153 & 0.000 & -0.104 \\
\hline Democracy & 1094 & 0.182 & 0.386 & 1547 & 0.127 & 0.333 & 0.000 & 0.055 \\
\hline
\end{tabular}

Panel B: Household characteristics

\begin{tabular}{|c|c|c|c|c|c|c|c|c|}
\hline & \multicolumn{3}{|c|}{ Caaguazú } & \multicolumn{3}{|c|}{ Asunción } & \multicolumn{2}{|c|}{ Comparison } \\
\hline & $\# O b s$ & Mean & $S d$ & $\# O b s$ & Mean & $S d$ & P-value & Difference \\
\hline HH Property Rights & 1094 & 0.896 & 0.306 & 1547 & 0.802 & 0.399 & 0.000 & 0.094 \\
\hline Land Property Rights & 1094 & 0.080 & 0.272 & 1547 & 0.075 & 0.263 & 0.605 & 0.005 \\
\hline HH Size & 1094 & 4.507 & 2.228 & 1547 & 4.515 & 2.382 & 0.931 & -0.008 \\
\hline Dwealing Index & 1094 & 1.320 & 1.496 & 1547 & -0.951 & 1.322 & 0.000 & 2.271 \\
\hline HH Goods Index & 1094 & 1.215 & 1.697 & 1547 & -0.875 & 2.009 & 0.000 & 2.090 \\
\hline
\end{tabular}

Notes: The variable Gender is a dummy that values 1 when the person is a woman. The variable Residence is a dummy and takes the value of 1 if the person resides in the same locality for at least 5 years. Education refers to the highest grade reached. The variable "Vote in 2013 " is a dummy that takes the value of 1 if the person
thinks democracy functions good or very good in Paraguay.

thinks democracy functions good or very good in Paraguay. of the place he/she lives, "Land Property Rights" is a dummy that takes the value of 1 if the person has the ownership of other asset such of the place he/she lives, "Land Property Rights" is a dummy that takes the value of 1 if the person has the ownership of other asset such as land. "HH Size" refers to the total number of members in the household. "Dwelling Index" is an index about the physical conditions of the household; it is created using principal component analysis (PCA), taking into account the following variables: type of house, ceiling of the house, floor, wall, access to water, bathroom type of drain, kitchen type of drain, and access to electricity. "HH Goods Index" is a household asset index and it is created using PCA, taking into account whether the house has a radio, tv, fridge, kitchen,
video/dvd, boiler, air conditioning, cable tv, cellphone, PC/laptop, microwave, electric oven, car/van, truck, motorbike, or bike. 
Table C9: Between-parties vote decisions - Abstention to missing

\begin{tabular}{lccc}
\hline \multicolumn{4}{l}{ Panel A: Voter-Fixed effects } \\
& Colorado & Liberal & Small parties \\
\cline { 2 - 4 } Open system & $(1)$ & $(2)$ & $(3)$ \\
& $0.0529^{* * *}$ & $0.0283^{* * *}$ & $-0.0812^{* * *}$ \\
Open*TC & $(0.010)$ & $(0.007)$ & $(0.010)$ \\
& $0.0298^{*}$ & $-0.0412^{* * *}$ & 0.0114 \\
Open*TCS & $(0.017)$ & $(0.013)$ & $(0.017)$ \\
& $0.0323^{*}$ & -0.0094 & -0.0230 \\
Constant & $(0.017)$ & $(0.013)$ & $(0.017)$ \\
& $0.5691^{* * *}$ & $0.1635^{* * *}$ & $0.2675^{* * *}$ \\
Observations & $(0.005)$ & $(0.004)$ & $(0.005)$ \\
Number of voter & 4,546 & 4,546 & 4,546 \\
R-squared & 2,415 & 2,415 & 2,415 \\
\hline
\end{tabular}

Panel B: Voter individual controls

\begin{tabular}{lccc}
\hline & Colorado & Liberal & Small parties \\
\cline { 2 - 4 } Open system & $(4)$ & $(5)$ & $(6)$ \\
& $0.0565^{* * *}$ & $0.0231+$ & $-0.0796^{* * *}$ \\
TC & $(0.020)$ & $(0.016)$ & $(0.017)$ \\
TCS & -0.0096 & -0.0032 & 0.0129 \\
& $(0.025)$ & $(0.019)$ & $(0.021)$ \\
Open*TC & -0.0021 & $-0.0326^{*}$ & $0.0347^{*}$ \\
& $(0.025)$ & $(0.019)$ & $(0.021)$ \\
Open*TCS & 0.0400 & -0.0365 & -0.0034 \\
& $(0.035)$ & $(0.027)$ & $(0.029)$ \\
Constant & 0.0226 & 0.0056 & -0.0282 \\
& $(0.035)$ & $(0.027)$ & $(0.029)$ \\
Observations & $0.5579 * * *$ & $0.1844^{* * *}$ & $0.2576^{* * *}$ \\
Number of voter & $(0.026)$ & $(0.020)$ & $(0.022)$ \\
R-squared & 4,546 & 4,546 & 4,546 \\
\hline
\end{tabular}

Notes: Individual controls include Married, Guaraní speaker, gender, dwelling index, household goods index, age and education. The specifications in Panel B include Interviewer-fixed effects. The variables TC (Corruption) and TCS (Corruption Social) correspond to the treatments. Robust standard errors clustered at the district level in parentheses. $* * * \mathrm{p}<0.01$, ** $\mathrm{p}<0.05,{ }^{*} \mathrm{p}<0.1,+\mathrm{p}<0.15$. 
Table C10: Between-parties vote decisions - multinomial Logit

\begin{tabular}{|c|c|c|c|c|c|c|}
\hline \multirow[b]{2}{*}{ Open System } & \multicolumn{2}{|c|}{ Colorado } & \multicolumn{2}{|c|}{ Liberal } & \multicolumn{2}{|c|}{ Small parties } \\
\hline & $\begin{array}{c}1.3652^{* *} \\
(0.172)\end{array}$ & $\begin{array}{c}1.3734^{* *} \\
(0.175)\end{array}$ & $\begin{array}{c}1.4056^{* *} \\
(0.211)\end{array}$ & $\begin{array}{c}1.4124^{* *} \\
(0.214)\end{array}$ & $\begin{array}{l}0.8402 \\
(0.123)\end{array}$ & $\begin{array}{l}0.8414 \\
(0.124)\end{array}$ \\
\hline Constant & $\begin{array}{c}3.7353^{* * *} \\
(0.323)\end{array}$ & $\begin{array}{c}2.1698^{* * *} \\
(0.495)\end{array}$ & $\begin{array}{l}1.1353 \\
(0.119)\end{array}$ & $\begin{array}{c}0.6625+ \\
(0.183)\end{array}$ & $\begin{array}{c}1.6882^{* * *} \\
(0.163)\end{array}$ & $\begin{array}{l}1.3506 \\
(0.356)\end{array}$ \\
\hline Voter controls & No & Yes & No & Yes & No & Yes \\
\hline Observations & 2570 & 2570 & 2570 & 2570 & 2570 & 2570 \\
\hline
\end{tabular}

Notes: Multinomial logit, reference abstention. Odds ratios reported. Individual controls include Married, Guaraní speaker, gender, dwelling index, household goods index, age and education. The specifications also include interviewer- and district-fixed effects. Robust standard errors clustered at the district level in parentheses. ${ }^{* * *} \mathrm{p}<0.01,{ }^{* *} \mathrm{p}<0.05,{ }^{*}$ $\mathrm{p}<0.1,+\mathrm{p}<0.15$

Table C11: Age (Cutoff $=47)$

\begin{tabular}{lcccc}
\hline & Colorado & Liberal & Small parties & Abstention \\
\cline { 2 - 5 } Open system & $(1)$ & $(2)$ & $(3)$ & $(4)$ \\
& $0.0536^{* * *}$ & 0.0138 & $-0.0467^{* * *}$ & $-0.0208+$ \\
Open*Age & $(0.016)$ & $(0.011)$ & $(0.014)$ & $(0.013)$ \\
& 0.0204 & 0.0203 & $-0.0359^{*}$ & -0.0049 \\
Open*TC & $(0.021)$ & $(0.015)$ & $(0.019)$ & $(0.018)$ \\
& 0.0032 & -0.0105 & -0.0101 & 0.0174 \\
Open*TC*Age & $(0.027)$ & $(0.019)$ & $(0.024)$ & $(0.023)$ \\
& 0.0326 & $-0.0406+$ & 0.0026 & 0.0054 \\
Open*TCS & $(0.036)$ & $(0.025)$ & $(0.032)$ & $(0.031)$ \\
& -0.0013 & 0.0188 & -0.0317 & 0.0142 \\
Open*TCS*Age & $(0.027)$ & $(0.018)$ & $(0.024)$ & $(0.022)$ \\
& 0.0314 & -0.0233 & 0.0042 & -0.0124 \\
Constant & $(0.036)$ & $(0.025)$ & $(0.032)$ & $(0.031)$ \\
& $0.4923^{* * *}$ & $0.1411^{* * *}$ & $0.2352^{* * *}$ & $0.1314^{* * *}$ \\
Observations & $(0.005)$ & $(0.004)$ & $(0.005)$ & $(0.004)$ \\
\cline { 2 - 5 } Number of voter & 5,185 & 5,185 & 5,185 & 5,185 \\
R-squared & 2,609 & 2,609 & 2,609 & 2,609 \\
\hline
\end{tabular}

Notes: Robust standard errors (cluster district) in parentheses. ${ }^{* * *} \mathrm{p}<0.01$, ** $\mathrm{p}<0.05,{ }^{*} \mathrm{p}<0.1,+\mathrm{p}<0.15$. Age is a dummy that takes value 1 when the age is less than 47 years (mean of the variable Age). The specifications of the tables include voter-fixed effects. The variables TC (Corruption) and TCS (Corruption Social) correspond to the treatments. 
Table C12: Language

\begin{tabular}{|c|c|c|c|c|}
\hline & Colorado & Liberal & Small parties & Abstention \\
\hline & $(1)$ & $(2)$ & $(3)$ & $(4)$ \\
\hline Open system & $\begin{array}{c}0.0853^{* * *} \\
(0.012)\end{array}$ & $\begin{array}{c}0.0349 * * * \\
(0.008)\end{array}$ & $\begin{array}{c}-0.0709^{* * *} \\
(0.011)\end{array}$ & $\begin{array}{c}-0.0493^{* * *} \\
(0.010)\end{array}$ \\
\hline Open*Language & $\begin{array}{c}-0.0853^{* * *} \\
(0.025)\end{array}$ & $\begin{array}{c}-0.0415^{* *} \\
(0.017)\end{array}$ & $\begin{array}{l}0.0188 \\
(0.022)\end{array}$ & $\begin{array}{c}0.1080^{* * * *} \\
(0.021)\end{array}$ \\
\hline Open*TC & $\begin{array}{l}0.0127 \\
(0.020)\end{array}$ & $\begin{array}{c}-0.0428^{* * *} \\
(0.014)\end{array}$ & $\begin{array}{l}0.0062 \\
(0.018)\end{array}$ & $\begin{array}{l}0.0238 \\
(0.017)\end{array}$ \\
\hline Open*TC*Language & $\begin{array}{l}0.0289 \\
(0.043)\end{array}$ & $\begin{array}{l}0.0424 \\
(0.030)\end{array}$ & $\begin{array}{c}-0.0652^{*} \\
(0.038)\end{array}$ & $\begin{array}{l}-0.0061 \\
(0.036)\end{array}$ \\
\hline Open*TCS & $\begin{array}{l}0.0161 \\
(0.021)\end{array}$ & $\begin{array}{c}-0.0039 \\
(0.014)\end{array}$ & $\begin{array}{c}-0.0305+ \\
(0.019)\end{array}$ & $\begin{array}{l}0.0183 \\
(0.017)\end{array}$ \\
\hline Open*TCS*Language & $\begin{array}{c}-0.0036 \\
(0.042)\end{array}$ & $\begin{array}{c}0.0418 \\
(0.029)\end{array}$ & $\begin{array}{c}0.0072 \\
(0.038)\end{array}$ & $\begin{array}{r}-0.0455 \\
(0.035)\end{array}$ \\
\hline Constant & $\begin{array}{c}0.4924^{* * *} \\
(0.005)\end{array}$ & $\begin{array}{c}0.1411^{* * *} \\
(0.004)\end{array}$ & $\begin{array}{c}0.2352^{* * *} \\
(0.005)\end{array}$ & $\begin{array}{c}0.1313^{* * *} \\
(0.004)\end{array}$ \\
\hline Observations & 5,185 & 5,185 & 5,185 & 5,185 \\
\hline Number of voter & 2,609 & 2,609 & 2,609 & 2,609 \\
\hline R-squared & 0.046 & 0.011 & 0.051 & 0.020 \\
\hline
\end{tabular}


Table C13: Education

\begin{tabular}{|c|c|c|c|c|}
\hline & Colorado & Liberal & Small parties & Abstention \\
\hline & $(1)$ & $(2)$ & $(3)$ & $(4)$ \\
\hline \multirow[t]{2}{*}{ Open system } & $0.1182^{* * *}$ & $0.0331^{* * *}$ & $-0.0875^{* * *}$ & $-0.0638^{* * *}$ \\
\hline & $(0.018)$ & $(0.013)$ & $(0.016)$ & $(0.015)$ \\
\hline \multirow[t]{2}{*}{ Open*Education } & $-0.0797^{* * *}$ & -0.0121 & $0.0315+$ & $0.0603^{* * *}$ \\
\hline & $(0.022)$ & $(0.015)$ & $(0.020)$ & $(0.019)$ \\
\hline \multirow[t]{2}{*}{ Open*TC } & 0.0037 & $-0.0526^{* *}$ & 0.0143 & 0.0346 \\
\hline & $(0.032)$ & $(0.022)$ & $(0.028)$ & $(0.027)$ \\
\hline \multirow[t]{2}{*}{ Open*TC*Education } & 0.0268 & 0.0294 & -0.0340 & -0.0222 \\
\hline & $(0.039)$ & $(0.027)$ & $(0.035)$ & $(0.033)$ \\
\hline \multirow[t]{2}{*}{ Open*TCS } & -0.0405 & 0.0135 & -0.0110 & 0.0379 \\
\hline & $(0.033)$ & $(0.023)$ & $(0.029)$ & $(0.027)$ \\
\hline \multirow[t]{2}{*}{ Open*TCS*Education } & $0.0822^{* *}$ & -0.0100 & -0.0266 & -0.0456 \\
\hline & $(0.039)$ & $(0.027)$ & $(0.035)$ & $(0.033)$ \\
\hline \multirow[t]{2}{*}{ Constant } & $0.4924^{* * *}$ & $0.1411^{* * *}$ & $0.2352^{* * *}$ & $0.1314^{* * *}$ \\
\hline & $(0.005)$ & $(0.004)$ & $(0.005)$ & $(0.004)$ \\
\hline Observations & 5,185 & 5,185 & 5,185 & 5,185 \\
\hline Number of voter & 2,609 & 2,609 & 2,609 & 2,609 \\
\hline R-squared & 0.043 & 0.009 & 0.051 & 0.008 \\
\hline \multicolumn{5}{|c|}{$\begin{array}{l}\text { Notes: Robust standard errors (cluster district) in parentheses. } * * * \mathrm{p}<0.01,{ }^{* *} \\
\mathrm{p}<0.05, * \mathrm{p}<0.1,+\mathrm{p}<0.15 \text {. Education is a dummy that takes the value of } 1 \text { when } \\
\text { Primary school and/or Basic education (from } 7 \text { to } 9 \text { grade) is reported as the max- } \\
\text { imum level of education, and } 0 \text { when respondents finished high school, technical } \\
\text { (middle) education and/or went to the university. The specifications of the tables } \\
\text { include voter-fixed effects. The variables TC (Corruption) and TCS (Corruption } \\
\text { Social) correspond to the treatments. }\end{array}$} \\
\hline
\end{tabular}




\section{Table C14: Awareness of information booklet news}

\begin{tabular}{|c|c|c|c|c|c|c|}
\hline \multirow[b]{3}{*}{ Total sample } & \multirow{3}{*}{ Control } & \multirow{3}{*}{$\begin{array}{l}\text { Information } \\
\text { Corruption }\end{array}$} & \multirow{3}{*}{$\begin{array}{c}\text { Information } \\
\text { Corruption }+ \text { Social }\end{array}$} & \multicolumn{3}{|c|}{ P-value } \\
\hline & & & & $\mathrm{C}-\mathrm{TC}$ & & TC-TCS \\
\hline & & & & & & \\
\hline Heard news on Futbol: & $34 \%$ & $35 \%$ & $35 \%$ & 0.5371 & 0.6805 & 0.8617 \\
\hline Heard news on Movie: & $84 \%$ & $84 \%$ & $86 \%$ & 0.8647 & 0.1425 & 0.2521 \\
\hline Heard news on Senators: & $89 \%$ & $88 \%$ & $91 \%$ & 0.6516 & 0.1565 & 0.1010 \\
\hline \multicolumn{7}{|c|}{ Importance of news: (1: "not at all"- 4:"very important") } \\
\hline Futbol & 2.65 & 2.59 & 2.58 & 0.1729 & 0.1138 & 0.8535 \\
\hline Movie & 3.09 & 3.04 & 3.06 & 0.1842 & 0.4578 & 0.5925 \\
\hline Senators & 2.40 & 2.43 & 2.58 & 0.5527 & 0.0001 & 0.0044 \\
\hline \multicolumn{7}{|l|}{ Asunción } \\
\hline Heard news on Futbol: & $38 \%$ & $39 \%$ & $38 \%$ & 0.7756 & 0.8764 & 0.7029 \\
\hline Heard news on Movie: & $95 \%$ & $95 \%$ & $96 \%$ & 0.9270 & 0.5493 & 0.6537 \\
\hline Heard news on Senators: & $96 \%$ & $95 \%$ & $97 \%$ & 0.5139 & 0.2918 & 0.1362 \\
\hline \multicolumn{7}{|c|}{ Importance of news: ( 1 : "not at all"- 4: "very important") } \\
\hline Futbol & 2.79 & 2.69 & 2.65 & 0.1077 & 0.0227 & 0.5597 \\
\hline Movie & 3.36 & 3.31 & 3.32 & 0.2915 & 0.4206 & 0.8135 \\
\hline Senators & 2.43 & 2.41 & 2.60 & 0.7398 & 0.0070 & 0.0109 \\
\hline \multicolumn{7}{|l|}{ Caaguazú } \\
\hline Heard news on Futbol: & $28 \%$ & $30 \%$ & $31 \%$ & 0.5030 & 0.3725 & 0.8438 \\
\hline Heard news on Movie: & $68 \%$ & $69 \%$ & $73 \%$ & 0.8069 & 0.1319 & 0.2650 \\
\hline Heard news on Senators: & $78 \%$ & $77 \%$ & $81 \%$ & 0.9055 & 0.2483 & 0.2627 \\
\hline \multicolumn{7}{|c|}{ Importance of news: (1:"not at all"- 4:"very important") } \\
\hline Futbol & 2.46 & 2.46 & 2.49 & 0.9175 & 0.6590 & 0.6358 \\
\hline Movie & 2.71 & 2.66 & 2.70 & 0.3941 & 0.8072 & 0.5706 \\
\hline Senators & 2.37 & 2.46 & 2.55 & 0.1361 & 0.0044 & 0.1924 \\
\hline
\end{tabular}

Notes: The table shows the percentages of participants that had heard about the information provided in each page of the information booklet. The p-values presented are from the mean difference tests between $\mathrm{C}$ (Control), TC (Corruption) and TCS (Corruption and social punishment) treatments. 